ISSN: 2146-3042

DOI:

\title{
Inter-Company Price Revisited: Passage From Monopoly Competition to the Realm of Corporate Financial Reporting*
}

\author{
Önder KAYMAZ** \\ Özgür KAYMAZ***
}

\begin{abstract}
This paper develops a theory of inter-company price or pricing (ICP) within the framework of monopoly competition as a form of imperfect rivalry and performs an analytical application showing its direct association with corporate financial reporting in general and corporate financial statements in particular. For this purpose, cost advantage and operating profit are served as catalysts to build the theory and apply it into accounting practice. In other words, cost advantage and operating profits are considered and constructed as keys to show and explain the interplay between ICP and corporate financial reporting in general and corporate financial statements in particular. Examinations document that given that businesses transact with each other under bilateral monopoly competition; ceteris paribus, the operating profit figure of the business with cost advantage will be higher than the operating profit (OP) figure of the business without cost advantage. Examinations further document that businesses transact with each other under bilateral monopoly competition; ceteris paribus, asset size, earnings before interest and taxes (EBIT), earnings before taxes (EBT) and hence net income/profit after tax (NPAT) figures of the business with cost advantage will always be higher than asset size, EBIT, EBT and therefore NPAT figures of the business without cost advantage.
\end{abstract}

Keywords: Inter-Company Price/Pricing, Corporate Financial Reporting, Financial Statements, Monopoly Competition.

Jel Classification: M40, M41, M48, M49.

\section{Şirketler Arası Fiyatlandırma Yeniden Ele Alındı: Tekelci Rekabetten Kurumsal Finansal Raporlamaya Uzanan Koridor \\ ÖZET}

Bu makale, eksik bir rekabet biçimi olarak tekelci rekabet çerçevesinde bir şirketler arası fiyat veya fiyatlandırma teorisi geliștirmekte ve bunun genel olarak kurumsal finansal raporlama ve özel olarak kurumsal finansal tablolarla doğrudan ilişsisini gösteren analitik bir uygulama gerçekleștirmektedir. Bu amaçla, malivet avantajı ve faalivet karı, teorivi olușturmak ve bunu muhasebe pratiğine uygulamak için katalizör görevi görmektedir. Diğer bir deyişle, maliyet avantajı ve faaliyet karları, genel olarak şirketler arası fiyatlandirma ile kurumsal finansal raporlama ve özel olarak kurumsal finansal tablolar arasındaki etkileşimi göstermek ve açılamak için anahtar olarak kabul edilir ve yapılandırllır. Yapılan analizler, işletmelerin birbirleriyle ikili tekelci rekabet altında işlem yapmaları göz önüne alındığında; tüm diğer unsurlar sabitken, maliyet avantajı olan ișletmenin faaliyet karı rakamı, maliyet avantajı olmayan işletmenin faaliyet karı rakamindan daha yüksek olduğunu belgelendirmektedir. Analizler ayrıca ișletmelerin ikili tekelci rekabet altında birbirleriyle ișlem yaptıklarını varsayımı altında; tüm diğer unsurlar sabitken, maliyet avantajı olan işletmenin varlık büyüklüğü, faiz ve vergi öncesi kazanç, vergi öncesi kazanç ve dolayısıyla vergi sonrası net kar rakamları her zaman maliyet avantajı olmayan işletmenin varlık büyüklüğ̈̈, faiz ve vergi öncesi kazanç, vergi öncesi kazanç ve dolaylsiyla vergi sonrası net kar rakamlarından daha yüksek olacaktır.

Anahtar Kelimeler: Şirketler Arası Fiyat/Fiyatlandırma, Kurumsal Finansal Raporlama, Mali Tablolar, Tekelci Rekabet.

JEL Sintflandirmast: M40, M41, M48, M49.

\footnotetext{
* Bu makale, 23-25 Nisan 2021 tarihleri arasında gerçekleştirilen VI. Uluslararası Muhasebe ve Finans Sempozyumunda bildiri olarak sunulmuştur.

Makale Gönderim Tarihi: 08.05.2021, Makale Kabul Tarihi: 25.06.2021, Makale Türü: Kuramsal

** Dr.,Clarion University (U.S.), kaymazonder@yahoo.com, Corresponding Author, Theoretical Research, ORCID: 0000-0001-9875-537X

*** Dr., Turkish Airlines Inc. (THY A.O), okaymaz@thy.com, Theoretical Research, ORCID: 0000-0003-1287-

7873. Opinions/views here do not belong to nor represent those of Turkish Airlines Inc.
} 


\section{BACKGROUND AND PRIOR LITERATURE}

When units or divisions in a company or when companies in a group company (such as holdings) make transactions among themselves, unlike the transactions they would make with outsiders, the applicable price to be charged to those goods or services that become the subject matter of the exchange or transaction is known as "inter-company price" (hereinafter referred to as "ICP”) in accounting and economics literature. ${ }^{1}$

As put in Mathis and Koscianski (2002), unlike perfect competition where there are countless buyers and sellers (suppliers), in monopolies, there is one single seller with a countless number of buyers. The seller, because of its power this way, is known as monopolist. The product the monopoly provides to the market is such differentiated that it is quite hard to find a substitute in the market. Entry into the monopoly market is very hard (e.g. economies of scale, exclusive input control, rapid production expansion facility, advertising, limit pricing etc.).

Mathis and Koscianski (2002) suggests that concerning the quality and the amount of the information as for the nature and the structure of the market, although there is no such an "a priori or ex-ante" requirement, it could also be likely that market consumers (i.e. purchasers of the good offered by the monopoly) may have inadequate information (e.g. attributes of the goods, alternative price-s and so on). All these general characteristics of monopolies suggest that monopolists, unlike the small sellers in perfect competition, are not price takers. As they can indeed influence the market price owing to the monopoly power or strength they enjoy, they might rather partially set the price where there might be no room for bargaining nor negotiating.

Mathis and Koscianski (2002) notes that monopoly power is usually purported to refer to pure monopoly strength as there is one single seller of the product in the market if that happens. In the real life, there are frequently, albeit not perfect, product substitutes in the market. It could be that there can be one single monopolist in the market. The monopolist may exert some influence on the market price, yet, it cannot price its product as much as it wants. This is again a demand-and-supply issue; meaning that, the higher the price, the lower the demand will be. Monopolist will know that if it charges too high price for the product it offers, it may not get the aggregate demand since there may be some loss on the degree of demand for the product. Therefore, monopolists are assumed to have a demand curve with a negative slope.

Mathis and Koscianski (2002) contends that the monopolist that can affect the market price is not a price taker unlike a regular seller (producer) in a perfect competition setting. Thus, being a monopolist necessitates that the market price be higher than the marginal revenue. In more technical words, both over the short and long runs, firm profit maximization happens at the point where marginal revenue (price) cuts off marginal cost, given that price is

\footnotetext{
${ }^{1}$ In the literature, such terms as “ intra-company price ”, “ inter-company price ”, “ intra-group price ”, “ intergroup price ”, “ intra-firm price ”, “ inter-firm price ”, “ internal price ”, “ internal company price ”, or more popularly “ transfer price”, etc. are all used interchangeably. In this paper, inter-company price or intercompany pricing (meaning ICP) will be used as the relevant term because of the nature of its subject, being monopoly competition and its behavior that affect accounting stakeholders and their financial decision processes. Likewise, ICPs is meant to refer to inter-company prices.
} 
higher than the marginal revenue. Hence, in monopolies, there are some spaces for extra or abnormal firm profits or yields in return.

There is a developed body of ICP literature (e.g. Amershi and Cheng, 1990; Baldenius et al. 1999(a), 1999(b), 2004 and 2006; Bierman, 1959; Buus, 2006; Cook, 1955; Cravens, 1997; Dawson and Miller, 2000; Dean, 1955; Edlin and Reichelstein, 1995; Greene, 1969; Göx and Schöndube, 2004; Hart, 1983; Hirshleifer, 1956; Horst, 1971; Jie-a-Joen and Sleuwagen, 1997; Kassicieh, 1981; Korn and Lengsfeld, 2007; Machlup, 1967; Mathis and Koscianski, 2002; Mervillel and Petty, 1978; Narayanan and Smith, 2000; Pfeiffer and Wagner, 2007; Schjelderup and Sørgard, 1997; Schmidt, 1997; Thomas, 1980; Zhao, 2000, etc.).

For instance; examination by Hirshleifer (1956) is the early and indeed yet the leading study. He argues that in monopolies, as different from perfect competitions, ICPs will be established differently. In particular, if there are two divisions in a business, one product provider and one purchaser, the ICP of the buying or purchasing unit will be the identical figure of what the marginal cost volume of the supplying firm unit will be. On the other hand, in perfect competitions, since prices are equal to marginal costs there, ICP will be set at such a point where the marginal revenue cuts off the marginal costs.

Thomas (1980) makes an ICP analysis in the context of some imperfect competition states/settings. What he basically suggests is that firm divisions may be willing to maximize their profits but not always to maximize the profit volume of the entire firm which he defines as central office (headquarter). In other words, it will be misleading to argue that the divisional managers will always try to maximize their book profits by producing in such a level which is the optimum one for the whole business. This indicates the goal incongruence problem that Hirshleifer (1956) did not explicitly consider. Hirshleifer rather suggested how ICP, both divisionally and parentally, will look under what goal congruence state stipulates for the intra-firm divisions and the central office.

Thomas envisages two firm divisions, a manufacturing and a distributing division, which Hirshleifer studied before. Assuming that there is no intermediate market, manufacturing division acts as internal monopoly and distributing division acts as internal monopsony. Namely, there is only one seller and one buyer of the firm product that is transferred among the firm divisions. Thomas treats the intra-firm divisions as to their having increasing, decreasing or horizontal marginal costs. He shows that transfer outputs, transfer prices, total profits, divisional book profits do all differentiate across both the divisions besides the central office, given all the three cost states.

Baldenius et al. (1999a) consider market-based ICPs within the setting of the intrafirm discounts that are the following materializations of the cost variances between external and internal selling transactions. The scholars suggest that if the supplying firm division has a monopoly power over the other intra-firm divisions, it is not the cost differences accounting for the suitability of the discounts on the intra-company transactions. Performing a sensitivity analysis of the degree of optimal discounts, the scholars contend that the market-based prices with a discount offer that is optimally set might well perform. Baldenius et al. (1999b) treat the basis to build the ICPs. They argue that negotiated-based ICPs might offer better venues than cost-based pricing scheme. However, they also note that when buyer investments are 
core to the firm and the selling business unit has inadequate flexibility, a standard cost-based ICP scheme can prove to be more efficient way of pricing than the pricing with negotiation.

Baldenius et al. (2004) show how managerial and taxational objectives of a business organization could be combined to refer to ICP. They particularly examine pricing patterns of multinationals when the (income) taxation regimes are subject to differ for the individual corporate divisions or units. They contend that the optimal (internal) ICP is supposed to be a product of a weighted average of the pre-tax marginal cost and the favored price that the terms of arm's length reveal or stipulate. Göx and Schöndube (2004) suggest that the removal of the agency problem may serve for the establishment of the firm commitment when we cannot monitor ICPs. The reason is the setting of the ICPs above the marginal costs. Assuming that the pricing decision is delegated to the manager, the scholars further argue that disturbing the agency problem may also be helpful in striking the right balance between incentives and risks while lowering the degree of the intensity of competition.

Buus (2006) shows that some mark-up figure added up to the average cost of the supplying intra-firm division may reveal the optimal ICP figure, irrespective of the specific terms of market for intermediate or final product (goods or services, tangibles or intangibles). One would argue that the scholar favors the cost-based ICP scheme. Discussing external and internal ICP in multidivisional businesses, Baldenius and Reichelstein (2006) suggest that we may see a double marginalization once the internal corporate transfers are priced at the prevailing market value. The scholars propose that when the capacity is constrained, an appropriately selected proportional discount enhances the aggregate business profits. Supposing that external market demand has a constant price elasticity, $\varepsilon$, and the unit variable cost for the internal company transfer is $c_{i}(\theta)=c(\theta)-k$, the ICP, ICP (p), will be obtained as: $\operatorname{ICP}(p)=p^{*}[1-(1 / \varepsilon)]-k$, where $k$ is the incremental revenue figure. In here, ICP is basically equal to the external marginal revenue, adjusted with the internal marginal revenue figure.

Dabson and Waterson (2007) researches the impact of competition vis-à-vis industrywide vertical price fixation on bilateral oligopoly. They argue that when retail price and ICP value are governed by bilateral negotiations, finalized market results will be identical with those to be established under joint monopoly. Brust et al. (2008) investigates the effect of incremental cost markups on successive monopoly structure that goes with downstream promotion. They consider a world with a game of two-players, one acting monopoly manufacturer that is upstream company and one acting monopoly retailer that is downstream company. They find that should the monopoly manufacturer opt for rising the ICP value charged to the monopoly retailer, the marginal yield that is connected with promotional engagement will be negatively affected, which will further result in the fall in the quantity of promotion and thereby of consumer demand as well.

Shor and Chen (2009) studies the interplay among decentralization, ICP and tacit collusion. They argue that if all of the companies act together and cooperate in a way to boost final prices to quasi monopoly levels through adjusting ICPs up they would realize profit. Pfeiffer et al. (2011) investigates cost-based ICP in the setting of incomplete contracts and information asymmetry. They consider the price markup as a proxy to capture monopoly power supplier enjoys under monopoly rivalry where there is better cost information that the supplier has and that makes the supplier superior relative to the buyer that suffers from lack of cost information. 
Schon (2012) argues that a significant amount of upfront investment along with a mutual investment can keep markets from running effectively as it can give a rise to bilateral monopoly. The scholar further argues that ICP charged at marginal cost would be picked should an upfront investment be present.

Matsui (2012) examines the cost-based transfer pricing with the involvement of R\&D risk aversion in a vertically integrated supply chain platform for a divisionalized business. Developing an economic model that allows the scholar to compare full-cost pricing versus variable-cost pricing methods, the scholar shows that given that there is no uncertainty and there is risk neutrality, corporate profit under full-cost ICP value will surpass the corporate profit to be established under variable-cost ICP value. The scholar also finds that when a relatively significant amount of risk exposure is implicated then it is the other way around.

Yao (2013) studies ICP with arm's length principle, tax revenues and endogenous location choices. The scholar documents that ICP level does both relate to taxation policies as well as location preferences of companies. Contrary to the myth, the scholar contends that policies that mandate strict implementation of arm's length principle does not indeed lead to increases in tax revenues.

Kaiser (2014) shows that cost-based ICP is going to beat negotiation-based ICP should the products happen to be good substitutes. Johnson et al. (2016) investigates dual ICP with external and internal trade when companies are decentralized. They analyze a firm with two units, i.e. selling (upstream) division and buying (downstream) division. They show that optimal dual ICP values are solely conditional on public information regarding the market price the upstream unit would charge externally. They argue that this strategy will signal the nature of production costs to the downstream unit.

Loffler (2017) examines ICPs within the realm of decentralized decision-making, incomplete (missing) contracts and information asymmetry, similar to Pfeiffer et al. (2011). The scholar proposes the application of cost-based ICP when there develops specific investment problem and when the upstream unit's costs are not arbitrary. The scholar contends that ICP governs intra-firm trade while generating incentives for investments that are geared towards and may increase value.

Johnson et al. (2018) studies different market-based ICP systems by considering two players that belong to a decentralized company, an upstream unit (supplier) and a downstream unit (buyer) both being agents. They assume that corporate headquarters (principal) has the information asymmetry problem and therefore cannot know how the upstream unit that has the private information is going to move. The scholars compare the performances of two market-based ICP policies: market-based ICP set by the company's competitor versus marketbased ICP set by the company's internal upstream unit. They document that this will cause varying levels of private-cost information from the end of downstream unit while influencing the level of internal corporate trade efficiency. They also show that (i) the size of external demand relative to that of internal demand shown for the upstream unit's good as well as (ii) the level of uncertainty vis-à-vis the costs that the upstream unit will incur will both drive the relative performances of the cited market-based ICP policies. 
Despite the fact that all those tackle ICPs from different perspectives, none of them shows the interaction between ICPs and cost advantages. Before going any further, it might be important to highlight an issue which is economies of scale. Thomas (1980) argues that, one of the firm divisions may have a lower cost scheme since it may exploit economies of scale advantage over the other. This is not something unreasonable, because, we know that economies of scale that might occasion through division of labor, specialization etc. may mitigate costs of the firms (e.g. production costs or cost to manufacture etc.) as businesses will be able to produce more economic units with the same amount of costs figure then. In other words, from the perspective of production efficiency, business organizations benefiting from economies of scale advantage will obtain more economic utility.

It might be also important to remember that there can happen natural monopolies from time to time where government agents assume the role of the monopolist as they might be the only supplier of the goods or services which would not be or made available otherwise (e.g. energy sector, telecommunication industry, construction (e.g. public transportation) industry etc.).

This paper is not interested in the influence of economies of scale or scope pertaining to the establishment of ICPs. Rather, it is interested in treating ICP issue with or without the state of cost advantage (which grows on its firm-specific prospect) and showing its connection with companies' financial statements in particular and corporate financial reporting in general when the market is monopoly. There is no study like this, to the best of our knowledge, that explores the effect of cost advantages on ICPs and hence on operating profit figures of the businesses in monopolies. Even though economies of scale advantage may be one of the technical reasons underlying firms' cost advantages, as firms' corporate governance structures might by definition include scale economies, this examination argues that it is the significant difference of governance structures or skills that creates cost advantages or leads to cost disadvantages. However, it does not mean at all that, governance is the exclusive foundation for generating corporate cost advantage.

As to be seen from the previous discussions, although there is a developed body of ICP literature, the ICP literature is in fact silent in documenting any direct linkage that (we argue and show) does exist between ICP and accounting. To the best of our knowledge, this is the first study to break this silence. This paper is solely motivated to develop a financial theory of ICP economics and thereby show its direct association with corporate financial reporting in general and corporate financial statements in particular. To this end, the remainder of this paper is organized as follows. Section Two (2), the next section, examines monopoly competition without cost advantage while providing a business case. Section Three (3) examines monopoly competition with cost advantage while providing a business case. Section Four (4) establishes the equilibria obtained under monopoly rivalry vis-à-vis competition with and without cost advantages. It also provides a remedy to duality problem. Section Five (5) makes an application (analytical examination) to corporate financial reporting world. It shows the impacts of ICP analysis on the corporate financial statements for 
the business organizations that run their activities under monopoly competition. And finally, section Six (6), concludes this paper with some propositions. ${ }^{2}$

\section{MONOPOLY COMPETITION WITHOUT COST ADVANTAGE}

In this section, we build a model and show how ICPs may be set under monopolies when none of the intra-group firms or businesses has any cost advantage. Suppose that there are two intra-group firms, financing business and purchasing business, each belongs to the firm ABC running a particular business. The financing business lends fund (money) to the purchasing business for the satisfaction of its purchasing need. The financing business is the only seller (provider) of the product (fund) while the purchasing business is the only purchaser of the product (fund) the financing business supplies to. The purchasing business uses this fund to buy some special products and sells them to several manufacturing businesses in the market that further process and sell out. follows.

The average unit operating revenue (price) function for both the businesses, $\mathrm{P}(\mathrm{R})$ is as

$$
\mathrm{P}(\mathrm{R})=\alpha-\psi \mathrm{q}
$$

conditional on $P, \alpha, q>0$. q represents the output quantity. The financing business, $F$, has a cost structure of $C_{f}=\beta+\gamma q$ and the purchasing business, $P$, has $C_{p}=\beta+\gamma q$, conditional on $C_{f}, C_{p}, \beta>0 . C_{f}$ stands for the average unit operating cost of the financing business, $C_{p}$ for the average unit operating cost of the purchasing business. Costs are everywhere differentiable such that $\mathrm{C}_{\mathrm{f}}{ }^{\prime}>0, \mathrm{C}_{\mathrm{p}}{ }^{\prime}>0$.

Among the main assumptions underlying the above model are:

- $\quad$ there are no taxes

- there are two intra-group firms transacting under the terms of bilateral monopoly competition, in particular:

- the financing business acts as internal monopoly (monopolist), the purchasing business acts as an internal monopsony (monopsonist)

- $\quad$ both the firms are decentralized so that they may decide on how to price and how much to produce their own goods/services (departmental products)

- $\quad$ both the firms have an identical bargaining power

- $\quad$ there is no capacity constraint

- $\quad$ information (unlike the competition) is perfect

- $\quad$ operating costs for the competing intra-group firms are cost of funding per se

\footnotetext{
${ }^{2}$ This paper is based on and an extended/updated version of Kaymaz (2009)'s unpublished doctoral dissertation. One can also refer to such empirical examinations as Kaymaz and Kaymaz (2012), Kaymaz et al. (2010) for drivers or profitability of commercial banks while also visiting the study by Kaymaz et al. (2015) which brings a new approach to the linkage extant between corporate financial reporting and performance. In particular, Kaymaz and Kaymaz (2019) that is similar to this paper in nature specifically undertakes a theoretical and practical approach within the framework of oligopoly competition/markets unlike this study. So, please refer to that one as well and consider it in combination with this paper. In addition to that, this paper was presented as a "Proceeding" in ISAF 2021 (VI. International Symposium on Accounting And Finance) organized in 23-25 April 2021.
} 
- $\quad$ costs are symmetrical

- $\quad$ both the intra-group firms have fixed and variable cost components

- $\quad$ all the functions are linearly specified

- $\quad$ there is no another transaction

- $\quad$ the intra-group firms earn one source of operating revenue or income which is the sales revenue and bear one source of operating expense which is the cost of sales

- $\quad$ there is neither any other type of revenues (other than operating revenue) nor any other type of costs (other than operating cost) for the intra-group firms

- $\quad$ both the intra-group firms have increasing cost structures, meaning that none of the intra-group firms has cost advantages over the other (or any cost saving)

The reason underlying the last assumption is that operating or sales costs are the same with cost of funding in this model; as fund or money transfer, being the main (ordinary) course of business of the intra-group firms, is the subject-matter of the intra-group firms' trade. As the governance structure or quality of neither the intra-group firms is assumed to be any better than the other, both the businesses have increasing cost structures. We provide the model resolution as the following.

The objective (pay-off) function of the financing business (monopoly) can be specified as $\Pi=P^{*} q_{f}-\left(\beta+\gamma q_{f}\right)^{*} q_{f}$, where $P$ represents the average unit ICP that the financing business will charge and $\mathrm{q}_{\mathrm{f}}$ represents the output or quantity the financing business will be willing to supply. Following Hirshleifer (1956) and Thomas (1980), marginal revenue, MR, will sum the marginal cost volume of the purchasing business, $\mathrm{MC}_{\mathrm{p}}$, and the ICP of the financing business which is $\mathrm{ICP}^{\mathrm{f}}{ }^{3}$ Namely:

$$
\mathrm{MR}=\mathrm{MC}_{\mathrm{p}}+\mathrm{ICP}^{\mathrm{f}} \quad(\text { Statement or Equation \#1) }
$$

Deriving the total revenue (TR) which is $(\alpha-\psi \mathrm{q}) * \mathrm{q}$ as regards $\mathrm{q}$, we will obtain MR as $\alpha-2 \psi q$. Since the total cost volume of the purchasing business $\left(\mathrm{TC}_{\mathrm{p}}\right)$ is $(\beta+\gamma \mathrm{q}) * \mathrm{q}$, deriving it wrt. $\mathrm{q}$ will result in $\beta+2 \gamma \mathrm{q} . \beta+2 \gamma \mathrm{q}$ is the marginal cost function of the purchasing business which is $\mathrm{MC}_{\mathrm{p}}$. Accordingly:

$$
\operatorname{ICP}^{f}=(\alpha-2 \psi q)-(\beta+2 \gamma q) \text { or equivalently } \operatorname{ICP}^{f}=\alpha-\beta-2 q(\psi+\gamma)
$$

We should incorporate the value of $\operatorname{ICP}^{\mathrm{f}}$ into the objective function of the financing business in the place of $\mathrm{P}$ and optimize it as for $\mathrm{q}_{\mathrm{f}}$. Therefore,

$$
\partial\left(\alpha-\beta-2 q(\psi+\gamma) q_{f}-\left(\beta+\gamma q_{f}\right) * q_{f}\right) / \partial q_{f}=0 \quad \text { (Statement \#3) }
$$

which can be rewritten as:

\footnotetext{
${ }^{3}$ This is due to the fact that, when the financing business acts as an internal monopoly, it will let the internal monopsony, the purchasing business, equalize its net revenues [TR - ICP $]$ to its marginal costs $\left[\mathrm{MC}_{\mathrm{p}}\right]$, at the output level that is optimal to the financing business $\left[\mathrm{q}_{\mathrm{f}}\right]$. For this and for a concrete algebraic analysis, see Thomas (1980) for instance.
} 


$$
q_{f}^{*}=\frac{\alpha-2 \beta}{2(3 \gamma+2 \psi)}
$$

This is the optimal transfer quantity result for the financing business. From the Statement (\#4) above, it is obvious that the financing business of the firm ABC will be willing to supply or provide funds at the point where $\alpha$ exceeds $2 \beta$. Incorporating the Equation (\#4) into the Equation (\#2), we get an optimal dollar ICP value of the financing business as follows:

$$
\operatorname{ICP}^{f}=\alpha-\beta-2\left(\frac{\alpha-2 \beta}{2(3 \gamma+2 \psi)}\right)(\psi+\gamma)
$$

Concerning the resulting properties of the internal monopsony, the purchasing business, we should note that the ICP of the purchasing business, ICP ${ }^{p}$, will be set equal to the marginal cost of the financing business per se. ${ }^{4}$ Since $C_{f}=\beta+\gamma q, \mathrm{TC}_{\mathrm{f}}=(\beta+\gamma \mathrm{q}) * \mathrm{q}$. Plugging $\mathrm{q}_{\mathrm{p}}$ into $\mathrm{q}$ and deriving it with respect to $\mathrm{q}_{\mathrm{p}}$ results $\beta+2 \gamma \mathrm{q}_{\mathrm{p}}$, which is the marginal cost function the financing business is expected to feature. This suggests that, if we obtain the optimized quantity value of the purchasing business we will have the ICP of the purchasing business too. We know that as in the case of financing business, purchasing business will maximize its profits. Therefore,

$$
\begin{gathered}
\left.\Pi=\left(\alpha-\psi \mathrm{q}_{\mathrm{p}}\right) \mathrm{q}_{\mathrm{p}}-\left(\beta+\gamma \mathrm{q}_{\mathrm{p}}\right) \mathrm{q}_{\mathrm{p}}-\left(\beta+2 \gamma \mathrm{q}_{\mathrm{p}}\right)\right) \mathrm{q}_{\mathrm{p}} \quad \text { (Statement \#6) } \\
\partial \Pi / \partial \mathrm{q}_{\mathrm{p}}=0 \quad(\text { Statement \#7) } \\
q_{p}{ }^{*}=\frac{\alpha-2 \beta}{2(3 \gamma+\psi)} \quad \text { (Statement \#8) }
\end{gathered}
$$

Therefore, the optimal ICP of the purchasing business, ICP ${ }^{\mathrm{p}}$, can be stated as the following (Statement \#9 below):

$$
\beta+2 \gamma\left[\frac{(\alpha-2 \beta)}{2(3 \gamma+\psi)}\right]
$$

\subsection{A Business Case: Service Transaction}

Supposing that all the assumptions specified in this chapter hold, consider that the group firm $A B C$ has a revenue (price) function of $P(R)=100-0,5 q$ where $P(R)$ represents average unit operating revenue (income) and q represents output quantity. It has two firms, financing business (F) and purchasing business (P). The financing business lends fund (money) to the purchasing business for some purchasing need. The intra-group firms have cost functions such that $C_{f}=20+0,1 q$ and $C_{p}=20+0,1 q$, where $C_{f}$ stands for the average

\footnotetext{
${ }^{4}$ This is because when the purchasing business acts as an internal monopsony, it will let the internal monopoly, the financing business, equalize its revenues $\left[\mathrm{TP}^{\mathrm{p}}\right]$ to its marginal costs $\left[\mathrm{MC}_{\mathrm{f}}\right]$, at the output level that is optimal to the purchasing business $\left[q_{p}\right]$. For this and a concrete algebraic analysis, see Thomas (1980) for instance.
} 
unit operating cost of the financing business and $C_{p}$ is for the average unit operating cost of the purchasing business $(\mathrm{P})$. Cost and revenue figures are in dollars. ${ }^{5}$

Since the financing business acts as internal monopoly and the purchasing business as internal monopsony in this case, we would have two different quantity volumes and ICPs. Namely, for F, the transfer output and the ICP will read 23 units and \$52 respectively. On the other hand, for $\mathrm{P}$, the transfer output and the ICP will be 38 units and \$28 respectively.

Solution. Total pay-off of the financing business (monopoly) may be functionalized as $\Pi=P^{*} q_{f}-\left(20+0,1 q_{f}\right) * q_{f}$, where $P$ represents the average unit ICP that the financing business will consider and $\mathrm{q}_{\mathrm{f}}$ represents output or quantity of the financing business. Since MR will be equal to the aggregation of the marginal cost volume of the purchasing business and the ICP of the financing business, we will have:

$$
\mathrm{MR}=\mathrm{MC}_{\mathrm{p}}+\mathrm{ICP}^{\mathrm{f}} \quad(\text { Statement or Equation \#1) }
$$

$\mathrm{TR}=(100-0,5 \mathrm{q}) * \mathrm{q}$ and as a consequence of deriving it with respect to (wrt.) $\mathrm{q}, \mathrm{MR}=$ $100-\mathrm{q}$. Since $\mathrm{TC}_{\mathrm{p}}=(20+0,1 \mathrm{q}) * \mathrm{q}$, deriving it wrt. $\mathrm{q}$ results in $20+0,2 \mathrm{q}$ which is $\mathrm{MC}_{\mathrm{p}}$. Accordingly,

$$
\mathrm{ICP}^{\mathrm{f}}=80-1,2 \mathrm{q}_{\mathrm{f}} \quad(\text { Statement \#2) }
$$

Plugging ICP ${ }^{f}$ into $\Pi$ in the place of $P$ and $\max \Pi$ wrt. $\mathrm{q}_{\mathrm{f}}=\partial \Pi / \partial \mathrm{q}_{\mathrm{f}}=0$ that yields

$$
\mathrm{q}_{\mathrm{f}}^{*} \approx 23 \quad(\text { Statement } \# 3)
$$

Since the optimal quantity of the financing business is 23 units, we know that, from the Statement \#2 above, the ICP of the monopoly (ICP $)$ will be approximately $\$ 52$. Notice that, the ICP in perfect competition is the price level where marginal revenue equals marginal cost. This is because in perfect competition, markets are in equilibrium where prices are identical to marginal cost. Firms in perfect competition take the market price as given. However, we know that, under imperfect competition environment like monopoly, price is not equal to marginal cost, but rather to the sum of net marginal revenue and marginal cost. This is due to the fact that, prices are assumed to be greater than marginal costs so that firms in those imperfect markets may sustain equilibrium to stay in the market in the long run. Theory tells us that net marginal revenue, NMR, can be obtained by deriving pay-off or objective function of a given intra-group firm with respect to quantity. In perfect competition, since NMR is equal to zero, price (ICP) is given to be marginal cost alone. On the other hand, in imperfect competition, depending on the magnitude of NMR, ICP might be lower or probably higher than marginal cost volume.

For the internal monopsony which is the purchasing business, the calculations are different in that ICP of the purchasing business, ICP ${ }^{\mathrm{p}}$, is equal to the marginal cost of the financing business itself. Since $\mathrm{C}_{\mathrm{f}}=20+0,1 \mathrm{q}, \mathrm{TC}_{\mathrm{f}}=(20+0,1 \mathrm{q}) * \mathrm{q}$. Plugging $\mathrm{q}_{\mathrm{p}}$ into $\mathrm{q}$ and deriving it wrt. $q_{p}$ will result in $20+0,2 q_{p}$, which is the marginal cost structure and thus explains the cost behavior of the financing business. This suggests that, once we have the

\footnotetext{
${ }^{5}$ Suppose that this transaction happens in the year 2021. Suppose also that the intra-group firms do not have any other transaction in 2021.
} 
optimized quantity value of the purchasing business we will have the ICP of the purchasing business as well. We know that as in the case of the financing business, the purchasing business will maximize its profits. Therefore,

$$
\Pi=\left(100-0,5\left(q_{p}\right)\right) q_{p}-\left(20+0,1\left(q_{p}\right)\right) q_{p}-\left(20+0,2\left(q_{p}\right)\right) q_{p} \quad \text { (Statement \#4) }
$$

$\max \Pi$ wrt. $\mathrm{q}_{\mathrm{p}}$

$\mathrm{q}_{\mathrm{p}}^{*} \approx 38 \quad($ Statement \#5)

Thereby ICP ${ }^{\mathrm{p}}$ will read equal to almost $\$ 28$. Hence the result.

The next section examines monopoly competition where the seller (fund supplier or lender) enjoys cost advantage over the purchaser (borrower).

\section{MONOPOLY COMPETITION WITH COST ADVANTAGE}

In this section, we build a model and show how ICPs may be set under monopolies when at least one of the intra-group firms has cost advantage over the other(s). In this case, one of the given intra-group firms is assumed to internalize (have) cost advantage sustained from good corporate governance structures. Suppose that there are two intra-group firms, financing business (F) and purchasing business (P), each belongs to the group firm $\mathrm{ABC}$ running a particular business. The financing business lends fund (money) to the purchasing division for the satisfaction of its purchasing need. The financing business is the only seller (provider) of the product (fund) while the purchasing business is the only purchaser of the product (fund) the financing business supplies to. The purchasing business uses this fund to buy some special products and sells them to several manufacturing businesses in the market that further process and sell out.

The average unit operating revenue (price) function for both the businesses, $P(R)$, is given as follows.

$$
\mathrm{P}(\mathrm{R})=\alpha-\psi \mathrm{q}
$$

conditional on $\mathrm{P}, \alpha, \mathrm{q}>0$. $\mathrm{q}$, represents the output quantity. The financing business, $\mathrm{F}$, has a cost structure of $C_{f}=\beta-\gamma q$ and the purchasing business, $P$, has $C_{p}=\beta+\gamma q$, conditional on $C_{f}, C_{p}, \beta>0 . C_{f}$ stands for the average unit operating cost of the financing business, $C_{p}$ for the average unit operating cost of the purchasing business. Costs are everywhere differentiable such that $\mathrm{C}_{\mathrm{f}}{ }^{\prime}<0, \mathrm{C}_{\mathrm{p}}{ }^{\prime}>0$.

More specifically, among the main assumptions underlying the above model are that:

- $\quad$ there are no taxes

- there are two intra-group firms transacting under the terms of bilateral monopoly competition, in particular:

- the financing business acts as internal monopoly (monopolist), the purchasing business acts as an internal monopsony (monopsonist)

- $\quad$ both the firms are decentralized so that they may decide on how to price and how much to produce their own goods/services (departmental products) 
- $\quad$ both the firms have an identical bargaining power

- $\quad$ there is no capacity constraint

- $\quad$ information (unlike the competition) is perfect

- $\quad$ operating costs for the competing intra-group firms are cost of funding per se

- $\quad$ costs are asymmetrical

- $\quad$ both the intra-group firms have fixed and variable cost components

- $\quad$ all the functions are linearly specified

- $\quad$ there is no another transaction

- $\quad$ the intra-group firms earn one source of operating revenue or income which is the sales revenue and bear one source of operating expense which is the cost of sales

- $\quad$ there is neither any other type of revenues (other than operating revenue) nor any other type of costs (other than operating cost) for the intra-group firms

- the financing business has decreasing cost structure (cost advantage) while the purchasing business has increasing cost structure (cost disadvantage)

The reason underlying the last assumption is that operating or sales costs are the same with cost of funding in this model; as fund or money transfer, being the main (ordinary) course of business of the intra-group firms, is the subject-matter of the intra-group firms' trade. As the governance quality of the financing business is assumed to be sufficiently good and significantly better relative to the purchasing business, the financing business with cost advantage has a downward cost function while the purchasing business without any cost advantage has an upward cost function, both of which are everywhere differentiable for the purposes of optimization. We provide the model resolution as the following.

The objective (pay-off) function of the financing business (monopoly) can be specified as $\Pi=\mathrm{P}^{*} \mathrm{q}_{\mathrm{f}}-\left(\beta-\gamma \mathrm{q}_{\mathrm{f}}\right)^{*} \mathrm{q}_{\mathrm{f}}$, where $\mathrm{P}$ represents the average unit ICP that the financing business will charge and $\mathrm{q}_{\mathrm{f}}$ represents the output or quantity the financing business will be willing to supply. Following Hirshleifer (1956) and Thomas (1980), marginal revenue, MR, will sum the marginal cost volume of the purchasing business, $\mathrm{MC}_{\mathrm{p}}$, and the ICP of the financing business which is $\operatorname{ICP}^{\mathrm{f}} \cdot{ }^{6}$ Namely:

$$
\mathrm{MR}=\mathrm{MC}_{\mathrm{p}}+\mathrm{ICP}^{\mathrm{f}} \quad(\text { Statement or Equation \#1) }
$$

Deriving the total revenue (TR) which is $(\alpha-\psi \mathrm{q}))^{*} \mathrm{q}$ as regards $\mathrm{q}$, we will obtain MR as $\alpha-2 \psi q$. Since the total cost volume of the purchasing business $\left(\mathrm{TC}_{\mathrm{p}}\right)$ is $(\beta+\gamma \mathrm{q})^{*} \mathrm{q}$, deriving it wrt. $\mathrm{q}$ will result in $\beta+2 \gamma \mathrm{q} . \beta+2 \gamma \mathrm{q}$ is the marginal cost function of the purchasing business which is $\mathrm{MC}_{\mathrm{p}}$. Accordingly:

$$
\operatorname{ICP}^{\mathrm{f}}=(\alpha-2 \psi \mathrm{q})-(\beta+2 \gamma q) \text { or equivalently } \mathrm{ICP}^{\mathrm{f}}=\alpha-\beta-2 \mathrm{q}(\psi+\gamma) \quad \text { (Statement }
$$

We should incorporate the value of ICP $^{\mathrm{f}}$ into the objective function of the financing business in the place of $\mathrm{P}$ and optimize it as for $\mathrm{q}_{\mathrm{f}}$. Therefore,

$$
\left.\partial\left(\alpha-\beta-2 q_{(\psi}+\gamma\right) * q_{f}-\left(\beta-\gamma q_{f}\right) * q_{f}\right) / \partial q_{f}=0 \quad \text { (Statement \#3) }
$$

\footnotetext{
${ }^{6}$ See footnote supra 3.
} 
which can be redefined as:

$$
q_{f}^{*}=\frac{\alpha-2 \beta}{2(\gamma+2 \psi)} \quad \text { (Statement \#4) }
$$

From the Statement \#4 right above, it is obvious that the financing business of the group firm ABC will always lend or provide (supply) fund at the point where $\alpha$ exceeds $2 \beta$. Incorporating the equation (\#4) into the equation (\#2), we get an optimal dollar ICP value of the financing business as follows:

$$
\mathrm{ICP}^{f}=\alpha-\beta-2\left(\frac{\alpha-2 \beta}{2(\gamma+2 \psi)}\right)(\psi+\gamma) \quad(\text { Statement \#5) }
$$

Concerning the resulting properties of the internal monopsony, the purchasing business, we should note that the ICP of the purchasing business, ICP ${ }^{\mathrm{p}}$, will be set equal to the marginal cost of the financing business per se. ${ }^{7}$ Since $C_{f}=\beta-\gamma q, \mathrm{TC}_{\mathrm{f}}=(\beta-\gamma q) * \mathrm{q}$. Plugging $\mathrm{q}_{\mathrm{p}}$ into $\mathrm{q}$ and deriving it with respect to $\mathrm{q}_{\mathrm{p}}$ results $\beta-2 \gamma \mathrm{q}_{\mathrm{p}}$, which is the marginal cost function the financing business is exposed to. This suggests that, if we obtain the optimized quantity value of the purchasing business we will have the ICP of the purchasing business. We know that as in the case of the financing business, purchasing business will maximize its profits. Therefore,

$$
\begin{aligned}
& \left.\Pi=\left(\alpha-\psi \mathrm{q}_{\mathrm{p}}\right) \mathrm{q}_{\mathrm{p}}-\left(\beta+\gamma \mathrm{q}_{\mathrm{p}}\right) \mathrm{q}_{\mathrm{p}}-\left(\beta-2 \gamma \mathrm{q}_{\mathrm{p}}\right)\right) \mathrm{q}_{\mathrm{p}} \quad \text { (Statement \#6) } \\
& \partial \Pi / \partial \mathrm{q}_{\mathrm{p}}=0 \quad(\text { Statement \#7) } \\
& q_{p}{ }^{*}=\frac{\alpha-2 \beta}{2(\psi-\gamma)} \quad \text { (Statement \#8) }
\end{aligned}
$$

Therefore, the optimal ICP of the purchasing business, ICP ${ }^{\mathrm{p}}$, is obtained as:

$$
\beta-2 \gamma\left[\frac{\alpha-2 \beta}{2(\psi-\gamma)}\right] \quad(\text { Statement \#9) }
$$

\subsection{A Business Case: Service Transaction}

Supposing that all the assumptions specified in this chapter hold, consider that the group firm $A B C$ has a revenue (price) function of $P(R)=100-0,5 q$ where $P(R)$ represents average unit operating revenue (income) and q represents output quantity. It has two firms, financing business $(\mathrm{F})$ and purchasing business (P). The financing business lends fund (money) to the purchasing business for some purchasing need. The intra-group firms have cost functions such that $C_{f}=20-0,1 q$ and $C_{p}=20+0,1 q$, where $C_{f}$ stands for the average

\footnotetext{
${ }^{7}$ See footnote supra 3.
} 
unit operating cost of the financing business and $C_{p}$ is for the average unit operating cost of the purchasing business $(\mathrm{P})$. Cost and revenue figures are in dollars. ${ }^{8}$

As to be noticed from the cost functions (specifications) of the intra-group firms, unlike the monopoly case where none of the businesses has any cost advantage, in this monopoly case, the financing business has cost advantage over the purchasing business that has no such advantage. The reason is, as mentioned and assumed before, that the governance quality of the financing business is assumed to be sufficiently good and significantly better than that of the purchasing business suffering from cost disadvantage. Since the financing business acts as internal monopoly and the purchasing business as internal monopsony in this case, we will again have two different quantity volumes and ICPs. Namely, for F, the transfer output and the ICP will read 27 units and \$48 respectively. On the other hand, for P, the transfer output and the ICP will be 75 units and $\$ 5$ respectively.

Solution. Total pay-off of the financing business (monopoly) may be functionalized as $\Pi=\mathrm{P}^{*} \mathrm{q}_{\mathrm{f}}-\left(20-0,1 \mathrm{q}_{\mathrm{f}}\right) * \mathrm{q}_{\mathrm{f}}$, where $\mathrm{P}$ represents the average unit ICP that the financing business will consider and $\mathrm{q}_{\mathrm{f}}$ represents the output quantity of financing business. Since MR equals the sum of marginal cost volume of the purchasing business and ICP of the financing business, we will have:

$$
\begin{aligned}
& \mathrm{MR}=\mathrm{MC}_{\mathrm{p}}+\mathrm{ICP}^{\mathrm{f}} \quad(\text { Statement or Equation \#1)} \\
& \mathrm{TR}=(100-0,5 \mathrm{q}) * \mathrm{q} \text { and therefore } \mathrm{MR}=100-\mathrm{q} . \text { Since } \mathrm{TC}_{\mathrm{p}}=(20+0,1 \mathrm{q}) * \mathrm{q}, \mathrm{MC}_{\mathrm{p}}
\end{aligned}
$$
will be equal to $20+0,2 q$. Accordingly,

$$
\mathrm{ICP}^{\mathrm{f}}=80-1,2 \mathrm{q}_{\mathrm{f}} \quad(\text { Statement \#2) }
$$

Plugging ICP ${ }^{f}$ into $\Pi$ in the place of $P$ and $\max \Pi$ wrt. $\mathrm{q}_{\mathrm{f}}=\partial \Pi / \partial \mathrm{q}_{\mathrm{f}}=0$ that yields

$$
\mathrm{qf}_{\mathrm{f}}^{*}=27 \text { units (Statement \#3) }
$$

Since the optimal transfer quantity of the financing business is 27 units, from the Statement \#2 above, the optimal ICP of the monopoly (ICPf) will be ca. \$48. As with the previous case, for the internal monopsony which is the purchasing business, calculations are different such that ICP of the purchasing business, ICP ${ }^{\mathrm{p}}$, is equal to the marginal cost of the financing business. Since $\mathrm{C}_{\mathrm{f}}=20-0,1 \mathrm{q}, \mathrm{TC}_{\mathrm{f}}=(20-0,1 \mathrm{q}) * \mathrm{q}$. Plugging $\mathrm{q}_{\mathrm{p}}$ into $\mathrm{q}$ and deriving it wrt. $q_{p}$ resolves to $20-0,2 q_{p}$, which is the marginal cost of the financing business. Similar to the financing business, the purchasing business will maximize its profits as well. Therefore,

$$
\begin{aligned}
& \Pi=\left(100-0,5\left(q_{p}\right)\right) q_{p}-\left(20+0,1\left(q_{p}\right)\right) q_{p}-\left(20-0,2 q_{p}\right) q_{p} \quad \text { (Statement \#4) } \\
& \text { Max П wrt. } q_{p} \\
& q_{p}^{*}=75 \text { units } \quad(\text { Statement \#5) } \\
& \text { Therefore ICP }{ }^{p} \text { will be equal to } \$ 5 \text {. Hence the result. }
\end{aligned}
$$

\footnotetext{
${ }^{8}$ Suppose that this transaction happens in the year 2021. Suppose also that the intra-group firms do not have any other transaction in 2021.
} 
The figure below depicts what is suggested, where the same notation is used.

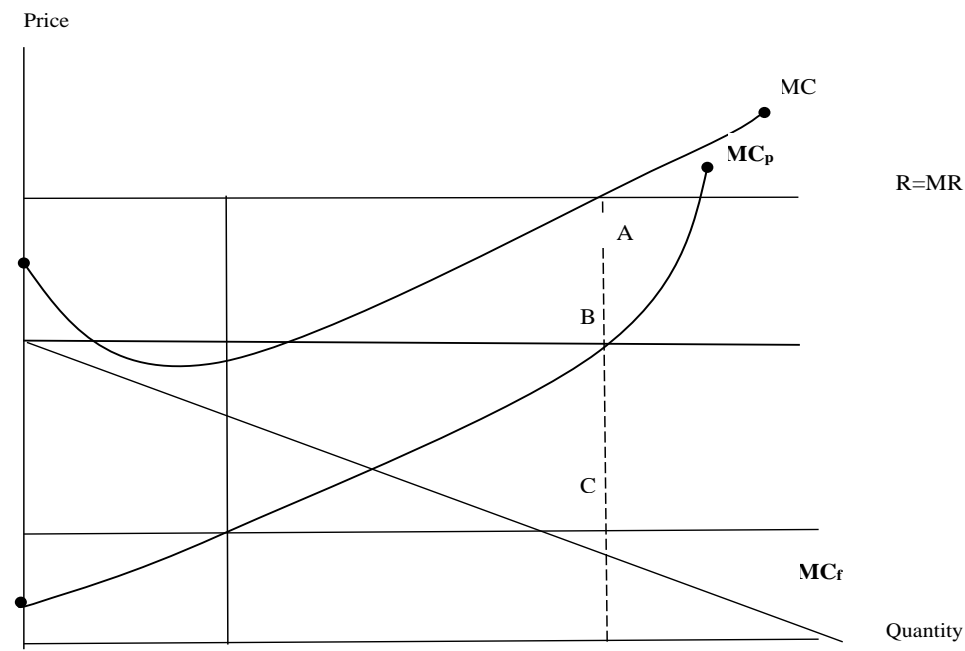

Figure 1. Decreasing And Increasing Costs: Financing Business Has Cost Advantage Over The Purchasing Business

Source: Adapted from Thomas (1980, p. 267)

The next section establishes the equilibria meaning equilibrium points for both the firms under monopoly while it also provides a resolution by solving the duality problem inherent to firms operating there.

\section{EQUILIBRIA}

In this section, we provide an in-depth and at-length discussion of the theoretical analyses performed in the preceding sections.

\subsection{What The Theoretical Examination Says For The Businesses in Monopoly: Need For Compromises}

With or without cost advantage, the financing business being the monopoly will always want to charge a price (ICP) that is higher than the one the purchasing business being the monopsony will be willing to pay. The financing business that turns out to be monopoly due to the absence of service providers will set the volume of the quantity (transfer output) at such a point which will be lower than what the purchasing business will be willing to pay out to the financing business. This is not surprising since we know that this is the expected result of being in monopoly competition; i.e. the nature of monopoly markets.

Changing the scenario from 'without cost advantage' to 'with cost advantage' influences the degree of the values; meaning the ICPs and the level of transfer outputs. The reason is that cost advantages differentiate ICP establishments of the intra-group firms even though both the firms make a transaction under monopoly competition in both the cost states. The table below summarizes the theoretical results obtained under both the monopoly cases. 
Table 1. Model Results Under Monopoly

\begin{tabular}{|c|c|c|}
\hline $\begin{array}{c}\text { Imperfect Competition Type: } \\
\text { Monopoly }\end{array}$ & \multicolumn{2}{|c|}{ Model Results: Optimal Functions In Equilibrium } \\
\hline Intra-Group Firms & Financing Business (Fund Supplier or Lender) & Purchasing Business (Borrower) \\
\hline ICP $^{*}$ & $\alpha-\beta-2\left(\frac{\alpha-2 \beta}{2(3 \gamma+2 \psi)}\right)(\psi+\gamma)$ & $\beta+2 \gamma\left[\frac{(\alpha-2 \beta)}{2(3 \gamma+\psi)}\right]$ \\
\hline ICP $^{*}$ & $\alpha-\beta-2\left(\frac{\alpha-2 \beta}{2(\gamma+2 \psi)}\right)(\psi+\gamma)$ & $\beta-2 \gamma\left[\frac{\alpha-2 \beta}{2(\psi-\gamma)}\right]$ \\
\hline $\mathbf{q}^{*}{ }^{*}$ & $\frac{\alpha-2 \beta}{2(3 \gamma+2 \psi)}$ & $\frac{\alpha-2 \beta}{2(3 \gamma+\psi)}$ \\
\hline $\mathbf{q}^{*}$ & $\frac{\alpha-2 \beta}{2(\gamma+2 \psi)}$ & $\frac{\alpha-2 \beta}{2(\psi-\gamma)}$ \\
\hline
\end{tabular}

In the upper table, $\mathrm{ICP}_{\mathrm{n}}{ }^{*}$ and $\mathrm{q}_{\mathrm{n}}{ }^{*}$ respectively refer to the optimal ICPs and quantities in the monopoly case where none of the intra-group firms has any cost advantage over the other. $\mathrm{ICP}_{\mathrm{c}}{ }^{*}$ and $\mathrm{q}_{\mathrm{c}}{ }^{*}$ respectively refer to the optimal ICPs and quantities in the monopoly case where the financing business utilizes cost advantage respective to the purchasing business. Notice that in the cost advantage case; the optimal quantity $\left(\mathrm{q}_{\mathrm{c}}{ }^{*}\right)$ for the financing business will be higher than the optimal quantity $\left(\mathrm{q}_{\mathrm{n}}{ }^{*}\right)$ for the financing business in " without cost advantage case ”.

Likewise, the optimal quantity $\left(\mathrm{q}_{\mathrm{c}}{ }^{*}\right)$ for the purchasing business will be higher than the optimal quantity $\left(\mathrm{q}_{\mathrm{n}}{ }^{*}\right)$ for the purchasing business. On the other hand, the optimal ICP $\left(\mathrm{ICP}_{\mathrm{c}}{ }^{*}\right)$ for the financing business will be lower than the optimal ICP $\left(\mathrm{ICP}_{n}{ }^{*}\right.$ ) for the financing business. Similarly, the optimal ICP $\left(\mathrm{ICP}_{\mathrm{c}}{ }^{*}\right)$ for the purchasing business will be lower than the optimal ICP $\left(\mathrm{ICP}_{\mathrm{n}}{ }^{*}\right)$ for the purchasing business. This makes sense because when prices get higher, quantities should get lower or vice versa. Recall that the demand curve is also downward sloping (suggesting an inverse association between price and quantity) even in the case of monopolies. 
Table 2. Findings From Numerical Examples Under Monopoly

\begin{tabular}{|c|c|c|}
\hline $\begin{array}{c}\text { Imperfect Competition Type: } \\
\text { Monopoly }\end{array}$ & \multicolumn{2}{|c|}{ Findings: Optimal Values in Equilibrium } \\
\hline Intra-Group Firms & Financing Business & Purchasing Business \\
\hline $\mathbf{I C P}^{*}{ }^{*}$ & $\$ 52$ & $\$ 28$ \\
\hline ICP $^{*}$ & $\$ 48$ & $\$ 5$ \\
\hline $\mathbf{q}^{*}{ }^{*}$ & 23 units & 38 units \\
\hline $\mathbf{q}^{*}$ & 27 units & 75 units \\
\hline
\end{tabular}

The above table summarizes the numerical findings building on theoretical results obtained under both the monopoly cases. In the upper table, $\mathrm{ICP}_{\mathrm{n}}{ }^{*}$ and $\mathrm{q}_{\mathrm{n}}{ }^{*}$ refer to respectively the optimal values of the corporate ICPs and quantities in the monopoly case where none of the intra-group firms has any cost advantage over the other. $\mathrm{ICP}_{\mathrm{c}}{ }^{*}$ and $\mathrm{q}_{\mathrm{c}}{ }^{*}$ stand for respectively the optimal values of the ICPs and quantities in the monopoly case where the financing business utilizes cost advantage over the purchasing business.

As to be seen from the upper tables, the level of the product (fund as transfer output) the monopoly being the financing business is willing to offer is higher in the state with cost advantage than the state without cost advantage. Therefore, ICP that the monopoly with cost advantage will consider is lower in the state with cost advantage than the state without cost advantage. For the monopsony being the purchasing business the situation is different. The amount of the product it wants to obtain is higher in the state with cost advantage than the state without cost advantage. In other words, monopoly's having a cost advantage influences not only itself but also the position of the monopsony which is the purchasing business.

However, values that have been obtained through the theoretical models and numerical cases are the individual optima for both the intra-group firms. They do not represent a unique solution where there may be a set satisfying the common interests of the entire involving parties. This is because there is a discrepancy between the price and the quantity offers the financing business is willing to propose and the price and the quantity volumes the purchasing business is willing to accept. In other words, irrespective of the cost advantage states, there is a duality problem as we have two different ICPs and two different transfer outputs in each the state. In order for making the internal corporate transaction eventually happen, those differentiating values have to be matched in one combination that will reveal one single ICP and one single transfer output figure in the end.

The solution is rather intuitive and compromising. As stated in the upper passage, since we have two different ICPs and transfer quantities in each the monopoly scenario, we have to find a cut-off point where the transacting intra-group firms, the financing and purchasing businesses, may come into an agreement. This implies a need for negotiation that 
will yield a possible common solution. Put differently, both the contractual parties, the intragroup firms, need to come to a common ground through negotiating the terms of this trade. The next step then is to discuss how this settlement may be achieved.

Looking back at the assumptions, we see that the intra-group firms have identical amount of bargaining power, which is indeed the key to resolving this duality problem. The financing business, despite the fact that it is the monopoly, cannot push the purchasing business to accept whatever the ICP or the transfer selling amount it may offer to. Remember that the purchasing business is the only purchaser of the product (fund) by the financing business. Therefore, it has the power of the monopsony. The same applies to the purchasing business as well. It cannot push the financing business as the financing business is the only provider or supplier of the product.

The upper passages suggest that, halving the aggregate ICPs (sum of the optimal or individual ICPs obtained for each intra-group firms) and the aggregate transfer outputs (the sum of the transfer quantities obtained for each intra-group firms) may generate a common solution, as the below tables illustrate. Remember that as it is assumed that there is no capacity constraint, whatever the purchasing business wants to source from the financing business, the financing business is always in a position to satisfy the demand of the purchasing business. Therefore, halving the values makes sense. The below table shows the model resolution under monopoly that writes the duality problem off. The letters have obvious meaning.

Table 3. Model Resolution Under Monopoly: Solving The Duality Problem

\begin{tabular}{|c|c|}
\hline $\begin{array}{c}\text { Imperfect } \\
\text { Competition: } \\
\text { Monopoly }\end{array}$ & $\begin{array}{c}\text { Bargaining Solution: ICP Settlement Under Equal Treatment } \\
\text { of Bargaining Strengths }\end{array}$ \\
\hline $\begin{array}{c}\text { Intra-Group } \\
\text { Firms }\end{array}$ & Financing/Purchasing Business \\
\hline $\mathbf{I C P}_{\mathbf{n}}{ }^{*}$ & $\frac{\left[\alpha-\beta-2\left(\frac{\alpha-2 \beta}{2(3 \gamma+2 \psi)}\right)(\psi+\gamma)\right]+\left[\beta+2 \gamma\left[\frac{(\alpha-2 \beta)}{2(3 \gamma+\psi)}\right]\right.}{2}$ \\
\hline $\mathbf{I C P}^{*}$ & $\frac{\left[\alpha-\beta-2\left(\frac{\alpha-2 \beta}{2(\gamma+2 \psi)}\right)(\psi+\gamma)\right]+\left[\beta-2 \gamma\left[\frac{\alpha-2 \beta}{2(\psi-\gamma)}\right]\right.}{2}$ \\
\hline $\mathbf{q}^{*}$ & $\frac{\left[\frac{\alpha-2 \beta}{2(3 \gamma+2 \psi)}\right]+\left[\frac{\alpha-2 \beta}{2(3 \gamma+\psi)}\right]}{2}$ \\
\hline
\end{tabular}




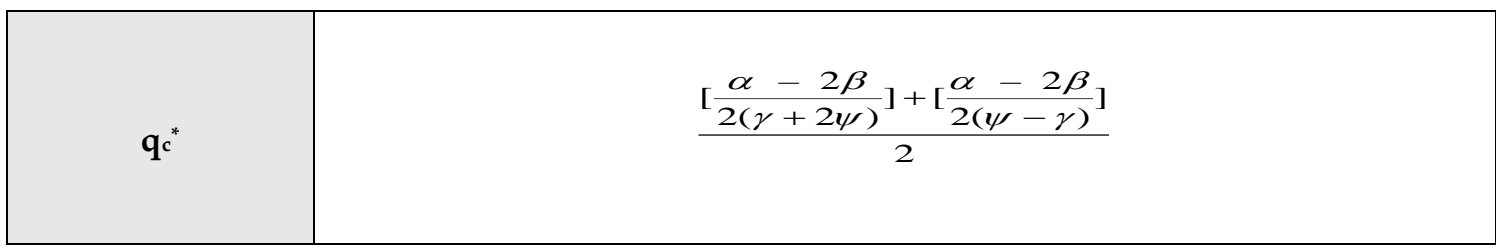

Similarly, resolution on the numerical findings will appear followingly, where the letters have obvious meaning.

Table 4. Resolution on The Findings From Business Cases Under Monopoly: Solving The Duality Problem

\begin{tabular}{|c|c|}
\hline $\begin{array}{c}\text { Imperfect } \\
\text { Competition: Monopoly }\end{array}$ & $\begin{array}{c}\text { Bargaining Solution: ICP Settlement Under Equal } \\
\text { Treatment of Bargaining Strengths }\end{array}$ \\
\hline Intra-Group Firms & Financing/Purchasing Business \\
\hline $\mathbf{I C P}_{\mathbf{n}}{ }^{*}$ & $\$ 40(=(52+28) / 2)$ \\
\hline $\mathbf{I C P}^{*}$ & $\$ 27(=(48+5) / 2)$ \\
\hline $\mathbf{q}^{*}{ }^{*}$ & 31 units $(=(23+38) / 2)$ \\
\hline $\mathbf{q c}^{*}$ & 51 units $(=(27+75) / 2)$ \\
\hline
\end{tabular}

On the realization of the bargaining process, the (unique) ICP with cost advantage, $\mathrm{ICP}_{\mathrm{n}}{ }^{*}$, will read a figure (\$27) that is lower than the (unique) ICP without cost advantage $(\$ 40)$ which is $\mathrm{ICP}_{\mathrm{c}}{ }^{*}$. In contrary to the ICP, the amount of the transfer output offered, $\mathrm{q}_{\mathrm{n}}{ }^{*}$, will be higher (51 units) in the state of cost advantage than the amount of transfer output in the state without cost advantage (31 units) which is $\mathrm{q}_{\mathrm{c}}{ }^{*}$. The reason for this inverse relationship is that the demand curve is downward sloping in monopolies, as touched before.

At this point, one can question what if the contractual (involving) parties, the financing and purchasing businesses, do not have the same negotiation or bargaining powers. The answer to this is also clear. In that case, the terms of negotiation will be exclusively up to the degree of bargaining powers of the intra-group firms. For instance, if the financing business were to have more bargaining power than the purchasing business, it would set the terms of negotiation more favorably (e.g. a higher ICP and a lower transfer quantity volume) at the expense of the purchasing business. On the contrary, if the purchasing business were to have more bargaining power instead, terms the negotiation stipulates in that case would favor (e.g. a lower ICP and a higher transfer quantity volume) itself at the expense of the financing business.

Another fundamental question concerns the level of capacity. In our case, the financing business has been assumed to have an unlimited capacity. We also know the answer 
to "what if the fund providing (financing) business does not have an unlimited capacity". In this case, there would be an upper bound which is the maximum amount of the units the financing business may offer to the purchasing business. If the bargaining strength of the purchasing business were to be higher than that of the financing business which were to have a restricted capacity to serve with, the purchasing business would yet obtain the maximum amount of transfer outputs the financing business can provide. The next section shows how theory applies to corporate financial reporting process.

\section{APPLICATION TO CORPORATE FINANCIAL REPORTING: THE EFFECTS OF ICP ANALYSIS ON THE FINANCIAL STATEMENTS OF THE BUSINESSES TRANSACTING UNDER MONOPOLY COMPETITION}

The preceding sections have performed theoretical ICP examinations which serve as a rigor basis for this section, as application in this paper expounds upon the specific results obtained in the course of theorization. However, in order to fully grasp the influence of ICP investigations, we will first need to understand the idea and present some essential properties underlying the corporate financial statements.

The main financial statements are balance sheets and income statements. A balance sheet shows the financial position (stance) of a given business, as of a point in time. On the other hand, an income statement reveals information on the financial performance of a business; therefore, it does not represent a point in time but rather a certain period or frame of time. Therefore, in a typical balance sheet, an equation, known as basic accounting or balance sheet equation, has to be satisfied as:

\section{Total Assets(Economic Sources)=Total Liabilities+Owner's Equity(Financial Resources)}

In the upper statement, “ total assets ”, the denominator on the left hand side, is meant to refer to the sum of the entire asset items a business has. In other words, assets which are often dubbed " actives (active accounts or items) of a balance sheet " are the economic sources of a business necessary to perform its operations and make profits. Total Liabilities and Owner's Equity, the right-hand side denominators, account for how a business finances its assets. For instance, if the business $\mathrm{A}$ is a self-financed enterprise, its total assets will read equal to its owner's equity since there will not be any liability (indebtedness) at all. If the business A prefers rather to finance all its sources (assets) using debts/borrowings alone, its total assets will be equal to its total liabilities since all the corporate sources would be financed using a complete foreign source (debt) in that case. In the real life, usually, businesses make use of both their internal (self) resources (e.g. capitals, reserves, profits etc.) and external or foreign resources (e.g. financial liabilities, trade liabilities, advances taken, deferred income, expense accruals etc.) to finance their assets. Therefore, liabilities and owner's equity which are often dubbed " passives (passive accounts or items) of a balance sheet " are the resources firms exploit to finance their economic sources being assets.

Assets boil down to two major components; i.e. current assets and non-current assets. The regular criteria to classify the assets so are (i) liquidity and (ii) term structure of the asset items among the others. For instance, a cash item is to be found under the uppermost portion of the current assets while trade receivables such as notes receivable account with a collection due date of two years will appear as a non-current asset in the balance sheet. Liabilities may 
be decomposed into two parts as well; i.e. short-term liability and long-term liability. The regular criterion to categorize the liabilities is the term structure of the liabilities used. This implies that a bank loan that is due within six months from now is to show up as a short-term liability while a bank loan that is due within five years from now will appear as a long-term liability piece.

The ICP analysis concerning the monopoly competition in this paper applies to intracompany dealings that are the transactions occurring within a group firm. Remember that in the sections concerning the establishment of the ICP algorithms of the monopoly competition, there have been two intra-group firms, one acting as an (internal) monopoly (fund provider or supplier) and the other one acting as an (internal) monopsony (the party requesting fund or borrowing). The fund provider has been the financing business and the fund providee has been the purchasing business.

Remember also that in monopoly scenarios, two different ICPs have been obtained. The solution there was rather compromising. Since we have obtained two different prices and quantities, through arbitration (bargaining), one unique ICP and transfer quantity have been achieved to be built. In doing so, the way-out was to halve those optimal ICP and output figures as the bargaining powers of both the intra-group firms were equal.

In the previous discussions, it has been shown that, cost advantage resulting from good governance skills in particular has led the ICPs and corresponding (transfer) quantities of the intra-group firms to be established quite differently from each other. In this section, the effects of two particular monopoly states on the financial statements of the involving group firms, namely 'monopoly competition without cost advantage' and 'monopoly competition with cost advantage', are discussed. In the former state, none of the intra-group firms has any cost advantage over the other. Therefore, cost functions of both the firms tend to increase in here. In the latter state, one of the intra-group firm, the financing business, has cost advantage over the purchasing business due to the fact that its governance structure is assumed to be sufficiently good and significantly better than that of the purchasing business. Therefore, cost function of the financing business tends to decline while the cost function of the purchasing business being the monopsony keeps increasing in there.

Notice that the financial outlook (appraisal) that is given below may easily be generalizable not only to the remaining cases, but also to any other cases that might be construed for the purposes of ICPs and cost advantage association.

\subsection{Monopoly Competition Without Cost Advantage}

Concerning the section 'monopoly competition without cost advantage', it has been assumed that none of the intra-group firms has any cost advantage over the other. Thus, they have been both subject to increasing cost structures. From the business case, remember that average unit operating revenue (price) $(R)=100-0,5 q, C_{f}=20-0,1 q$ and $C_{p}=20+0,1 q$, where $q$ represents the average unit output quantity, $C_{f}$ stands for the average unit operating cost of financing business, $\mathrm{F}$, and $\mathrm{C}_{\mathrm{p}}$ is for the average unit operating cost of purchasing business, $\mathrm{P}$. Cost and revenue figures were given in dollars. Remember also that financing business is the monopoly being the exclusive fund provider and purchasing business is the monopsony being the exclusive fund providee or grantee. In this case, it has been shown that, 
the (compromising) ICP is $\$ 40$ and the (compromising) output is 31 units, which is the common solution set.

In order to concretely show the effects of the upper ICP analysis on the regular financial statements (income statements and balance sheets especially) of the intra-group firms, we need to establish in the first place the close interaction among ICPs, transfer outputs/quantities and operating profit or loss figures. Once this is done, it will then be possible to build the financials (financial statements) appropriately. As the previous discussions have suggested, without knowing about the operating profit/loss denominator, it is not possible to reach to the net profit after tax (NPAT) volume which is the bottom line figure (usually the most important part therefore) of the corporate income statements. And, without having an NPAT volume, it will not be possible to draft a corporate balance sheet. Therefore, establishing the interplay between the numbers ICP analyses have suggested and the resulting operating profits/losses is the center to the discussion of this part of the paper. The next section examines this issue.

\subsubsection{The Interplay Between Operating Profits And ICPs}

In all the models, it has been assumed that average unit operating cost is the sum of average unit operating variable cost and average unit operating fixed cost. Generally speaking, a variable cost changes as the units produced or sold changes, while a fixed cost remains the same even if there is no production or sales as of a point of time, or even if the units produced or sold change. From cost and managerial accounting literatures, we know that overheads or overhead costs are probably the hardest cost items to be apportioned to the respective cost units for which some costs may incur. The main reason is that overheads consist of costs that are either fixed costs or both fixed and variable costs, besides indirect costs. In this respect, overheads are known as mixed costs in the accounting literature. Indirect costs (e.g. indirect labor costs, indirect material costs etc.) are among the overheads for instance. This is relevant for manufacturing businesses.

In this paper, operating (sales) costs particularly refer to funding or sourcing costs as our service transactions rely on fund exchange. The figure below depicts the behavior of sales costs. It shows that sales costs are given to be a combination of both fixed costs and variable costs. Thus, a sales cost (Y), in average units, may be expressed as follows.

$$
Y=\psi+\delta^{*} q \quad \text { (Statement or Equation \#1) }
$$

In the upper formula where the cost function is linearly specified, $Y$ refers to average unit sales cost that further boils down to two cost figures: $\psi$ as an average unit fixed cost value, $\delta^{*} \mathrm{q}$ as an average unit variable cost value that is exposed to differ once q changes.

Back in our case, the average unit cost structures of the financing and purchasing divisions are known. Specifically, ' $\mathrm{C}_{\mathrm{f}}=20+0,1 \mathrm{q}$ ' is the average unit operating cost of the financing division, while ' $\mathrm{C}_{\mathrm{p}}=20+0,1 \mathrm{q}$ ' is the average unit operating cost of the purchasing division. As revenues (incomes) are entirely operating revenues (incomes), costs are entirely operating costs or expenses likewise. Remember that it is assumed that (a) there is neither any other type of revenues (other than operating revenue) nor any other type of costs (other than operating cost) for the intra-group firms, (b) the intra-group firms earn only one source 
of operating revenue or income which is the sales revenue while bearing only one source of operating expense which is the cost of sales. Building on the upper statement, there remains no difference between an average unit cost (revenue) and average unit operating cost (revenue). In other words, total operating costs (expenses) which are costs of sales will be equal to total costs (expenses) while total operating revenue (income) which is the sales revenue will read equal to total revenues (income) in this paper. ${ }^{9}$

Sales Costs (\$)

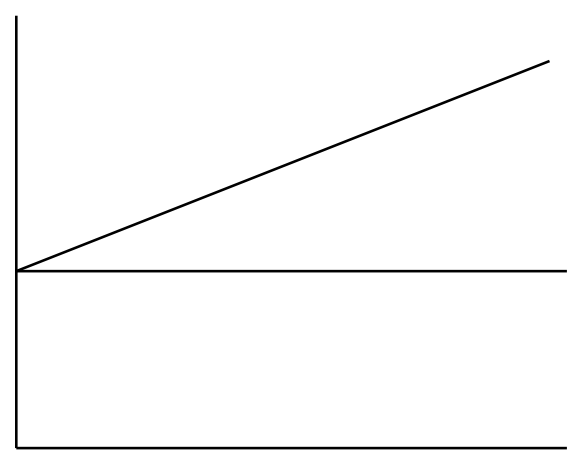

\section{Units Sold (Services Delivered)}

Figure 2. The Behavior of Sales Costs

We know that total sales costs correspond to the product of average unit cost by the number of units sold or delivered. Hence, rearranging the statement [1] above, we have:

\section{Total (Operating) Costs $=$ [Average Unit (Operating) Costs] $*$ [Number of Services Delivered/Sold] (Statement \#2)}

Thereby, it turns out that $((20+0,1 q) * q)$ will be the total (operating) cost figure of the financing division, while $((20+0,1 q) * q)$ will be the total (operating) cost figure of the purchasing division. $\mathrm{q}$ is the transfer output or quantity corresponding to the related ICP. Therefore, the compromising (common) transfer output figure of the financing division that has been found as 31 units corresponding to a compromising ICP of $\$ 40$ should be considered as $\mathrm{q}$ for the financing division. Likewise, the compromising transfer output figure of the purchasing division that has been found as 31 units corresponding to a compromising ICP of $\$ 40$ should be considered as $\mathrm{q}$ for the purchasing division. The common solution numbers for both the divisions are the same, owing to the bargaining procedure as we have seen.

We know that total revenue is equal to the product of price by quantity. Price refers to the ICP of the respective divisions. In other words,

Total Revenue $=I C P *$ Transfer Output or equivalently,

Total Revenue $=p^{*} q$

where the letters have obvious meanings.

\footnotetext{
${ }^{9}$ As the following discussions are also to verify, such definition will indeed prove to be quite helpful since the results will be sufficiently concrete and tractable to gather and to make solid inferences.
} 
We know that the difference between total revenue and total cost will deliver a profit or lost volume. As total revenue is the same as total operating revenue (income) and total cost is the same as total operating cost (expense) here, the difference will directly generate an operating profit or loss figure. In case total revenues outweigh total costs, there will be an operating profit for the businesses concerning the specific transaction as regards to a specified period of time. If the opposite holds, since there will be a negative contribution, there will be operating loss. Hence, operating profit might be written as follows:

$$
\text { Operating Profit (Loss) }=\text { Total Revenue (Operating Income })- \text { Total Cost }
$$

\section{(Operating Expense) (Statement \#3)}

Using the findings obtained from the respective business case presented before, we may obtain the operating profit figures for both the divisions now. For the financing division:

Operating Profit $=\left[\mathrm{TR}^{\mathrm{f}}\right]-\left[\mathrm{TC}_{\mathrm{f}}\right]$ which may be restated as:

$$
\text { Operating Profit }=\left[I C P^{f *} q_{f}\right]-\left[C_{f}^{*} q_{f}\right] \quad \text { (Statement \#4) }
$$

where $\mathrm{TR}^{\mathrm{f}}$ stands for the total operating (sales) revenue of the financing division, $\mathrm{TC}_{\mathrm{f}}$ for the total operating (sales) cost volume of the financing division, $\mathrm{q}_{\mathrm{f}}$ for the corresponding transfer output of the financing division, and $\mathrm{C}_{\mathrm{f}}$ for the average unit operating cost volume of the financing division. As to be easily recalled, the ICP of the financing division is $\$ 40$ and the transfer output is 31 units. Hence, the operating profit for the financing division will read the following:

Operating Profit $=[40 * 31]-[(20+0,1 *(31)) * 31]$ which is ca. $\$ 524$.

For the purchasing division:

Operating Profit $=\left[\mathrm{TR}^{\mathrm{p}}\right]-\left[\mathrm{TC}_{\mathrm{p}}\right]$ which may be restated as:

$$
\text { Operating Profit }=\left[I C P^{p *} q_{p}\right]-\left[C_{p}^{*} q_{p}\right]
$$

where $\mathrm{TR}^{\mathrm{p}}$ stands for the total operating (sales) revenue of the purchasing division, $\mathrm{TC}_{\mathrm{p}}$ for the total operating (sales) cost volume of the purchasing division, $\mathrm{q}_{\mathrm{p}}$ for the corresponding transfer output of the purchasing, and $C_{p}$ for the average unit operating cost volume of the purchasing division. As the ICP of the purchasing division is $\$ 40$ and transfer output is 31 units, the operating profit for the purchasing division will read the following:

$$
\text { Operating Profit }=[40 * 31]-[(20+(0,1 * 31)) * 31] \text {, which is ca. } \$ 524 \text {. }
$$

Remember the assumption that the intra-group firms earn only one source of operating revenue or income which is the sales revenue and bear only one source of operating expense which is the cost of sales. Accordingly; total operating expense volume above, TC, is found to be the same as cost of sales and total operating income volume above, TR, is found to be the same as sales revenue. All the other incomes or expenses will be non-operating incomes or expenses which are assumed to be zero (0) here. Acknowledging this, the next section 
establishes the income statements of the financing and purchasing businesses as the following.

\subsubsection{The Income Statements of The Financing \& Purchasing Businesses}

From the previous section, it has been seen that both the intra-group firms, the financing business and the purchasing business, realize a positive figure of operating profits that are close to each other. The reason is that they share an equal power of bargaining. We know that without knowing operating profit figures, we cannot go ahead with the preparation of the income statement. The bottom line, the net profit after tax (NPAT) figure, is absolutely up to the accurate identification of the operating profit figures of the businesses. For the financing business, a concise income statement is given as follows.

Table 5. Annual Income Statement For The Financing Business: Monopoly Competition Without Cost Advantage

\section{Annual Income Statement For The Financing Business}

For The Period Ending 2021 (in \$)

\begin{tabular}{|l|r|}
\hline & Dec' 21 \\
\hline (1) Sales Revenue & 1,240 \\
\hline (2) Total Costs (-) & 716 \\
\hline (3= (1)-(2)) Operating Profit (OP) & 524 \\
\hline (4) Non-Operating Income & 0 \\
\hline (5) Non-Operating Expenses (-) & 0 \\
\hline (6= (3)+(4)-(5)) Income (Earnings) Before Taxes (EBT) & 524 \\
\hline (7) (Corporate) Income Taxes (-) & 105 \\
\hline [8= (6)-(7)] Net Income (Profit) After Taxes (NPAT) & 419 \\
\hline
\end{tabular}

It is assumed that being annual and in US dollars, the upper income statement is prepared for the year ending 2021. The income statement construed right above is a traditional one that we frequently see around in the real life; therefore the costing system here uses the full costing approach. Remember that unlike variable costing system where only the variable costs are shown as operating costs, in full (absorption) costing systems, not only variable but fixed costs incurring during a specific period of time is recorded as cost (expense) items in the income statements -as was in our income statement as well.

It could also be that the upper income statement might have been prepared using the variable costing system. We know that financial statements prepared according to not full but to variable costing system should only entail variable elements, not fixed ones. Therefore, 
even though there will be no difference at the bottom line, in net profit after tax figure, the operating profit volumes will yet differ, depending upon which costing system we use. ${ }^{10} \mathrm{In}$ our case, for instance in the cost structures of the divisions, we are given a hybrid form of cost figures (fixed and variable average unit operating costs) as said early on, suggesting the use of full costing approach. Therefore, we may not use this system here. Moreover, this is out of the scope of this paper.

The one above (as referred to in Table 5) is a hypothetical income statement; therefore, items such as non-operating income or expenses are also assumed to be zero there. Further, the level of the income tax rate the financing division, F, is liable to pay when due, is given as $20 \%$. It is the tax rate applicable to the earnings before taxes (EBT) figure which is the tax base. Net income after taxes (NPAT) which is \$419 thus becomes EBT (\$524) netted of the tax due which is $\$ 105$. The similar assumptions and features holding for the financing division apply to the purchasing division as well. For the purchasing division, a concise income statement may be given as follows.

Table 6. Annual Income Statement For The Purchasing Business: Monopoly Competition Without Cost Advantage Income Statement For The Purchasing Business For The Year Ending 2021 (in \$)

\begin{tabular}{|l|r|}
\hline & ec'21 \\
\hline (1) Sales Revenue & 1,240 \\
\hline (2) Total Costs (-) & 716 \\
\hline (3= (1)-(2)) Operating Profit (OP) & 524 \\
\hline (4) Non-Operating Income & 0 \\
\hline (5) Non-Operating Expenses (-) & 0 \\
\hline (6= (3)+(4)-(5)) Income (Earnings) Before Taxes (EBT) & 524 \\
\hline (7) (Corporate) Income Taxes (-) & 105 \\
\hline [8= (6)-(7)] Net Income (Profit) After Taxes (NPAT) & 419 \\
\hline
\end{tabular}

Since we have established the income statements of the intra-group firms which are considered as corporate income taxpayers due to their resulting (positive) EBT volumes, we can now construe their balance sheets as follows. Notice that as long as EBT is positive, there will always be income taxes to be due and to be reported.

\subsubsection{The Balance Sheets of The Financing \& Purchasing Businesses}

From the income statement accounts, we got 'provision for taxes' (corporate income taxes), 'earnings before taxes' (tax base/taxable income) and 'net profit after tax balances'

\footnotetext{
${ }^{10}$ Bilginoğlu (1996)
} 
(net profit for the period). Provision for taxes or tax provisions and net profit for the period are the figures we need to incorporate into the balance sheets of the intra-group firms.

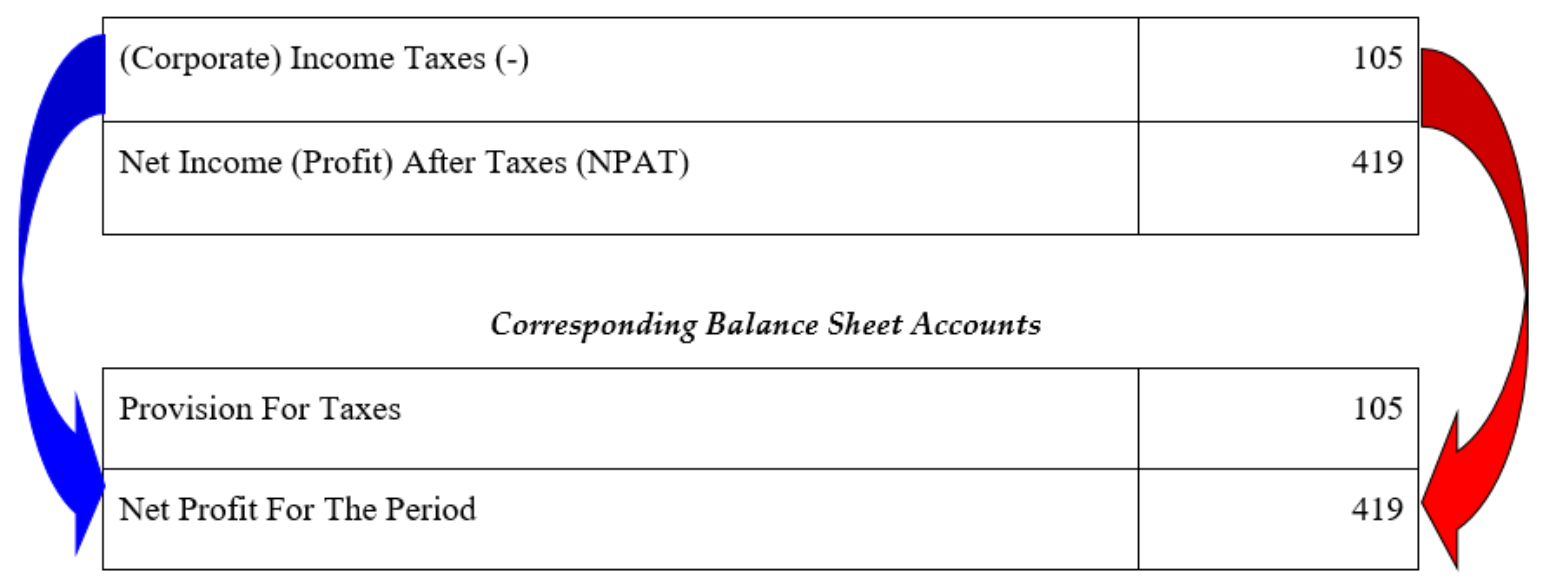

Figure 3. Transforming The Relevant Income Statement Accounts to The Balance Sheet Accounts of The Financing Business: Monopoly Competition Without Cost Advantage

In the balance sheet below, accounts (figures) except for the net profit for the period and the provision for taxes are hypothetical.

Table 7. Annual Balance Sheet of The Financing Business: Monopoly Competition Without Cost Advantage

\begin{tabular}{|l|r|}
\hline \multicolumn{2}{|c|}{ Annual Balance Sheet of The Financing Business As of The Year Ending 2021 (in \$) } \\
\hline Assets & Dec'21 \\
\hline Current Assets & 288 \\
\hline Cash & 424 \\
\hline Banks & 150 \\
\hline Inventories & 50 \\
\hline Other Current Assets & 912 \\
\hline Total Current Assets & 44 \\
\hline Net Fixed Assets & 10 \\
\hline Other Noncurrent Assets & 54 \\
\hline Total Non-Current (Fixed) Assets & $\mathbf{9 6 6}$ \\
\hline Total Assets & \\
\hline
\end{tabular}




\begin{tabular}{|c|c|}
\hline Liabilities and Owner's Equity & Dec’21 \\
\hline \multicolumn{2}{|l|}{ Short-Term Liabilities } \\
\hline Accounts Payable & 58 \\
\hline Provision For Taxes & 105 \\
\hline Other Current Liabilities & - \\
\hline Total Short-Term Liabilities & 163 \\
\hline Long-Term Debt & 120 \\
\hline Other Long Term Liabilities & 30 \\
\hline Total Long-Term Liabilities & 150 \\
\hline Total Liabilities & 313 \\
\hline \multicolumn{2}{|l|}{ Owner's Equity } \\
\hline Contributed Capital & 234 \\
\hline Net Profit For The Period & 419 \\
\hline Total Equity & 653 \\
\hline Total Liabilities \& Owner's Equity & 966 \\
\hline
\end{tabular}

As in the case of the financing division, the purchasing division will need to transpose the relevant income statement accounts (figures) to its annual balance sheet as the following.

\begin{tabular}{|l|r|}
\hline \multicolumn{1}{|c|}{ (Corporate) Income Taxes (-) Corresponding Balance Sheet Accounts } \\
\hline Net Income (Profit) After Taxes (NPAT) \\
\hline \multicolumn{1}{|c|}{ Cros } \\
\hline Provision For Taxes & 105 \\
\hline Net Profit Eor The Period & 419 \\
\hline
\end{tabular}

Figure 4. Transforming The Relevant Income Statement Accounts to The Balance Sheet Accounts of The Purchasing Business: Monopoly Competition Without Cost Advantage (in \$) 
Now that we know the balances of the relevant accounts of the balance sheet, a snapshot of the annual/yearly balance sheet of the purchasing division could be given as follows. In the balance sheet below, accounts (figures) except for net profit for the period and provision for taxes are hypothetical. Notice that the purchasing division, a corporate taxpayer like the financing division, seems to have a tax payable due or outstanding of \$105 which it did not pay out yet. Once it is paid, a relevant account (e.g. banks account) will decrease as much as the tax liability which is $\$ 105$ since the "provision for taxes" account will vanish from the balance sheet of the purchasing division. The same applies to the financing division as well. ${ }^{11}$

\subsection{Monopoly Competition With Cost Advantage}

Concerning the section 'monopoly competition with cost advantage', it has been stated that one of the intra-group firms, the financing business, has cost advantage over the purchasing business because its governance structure is assumed to be sufficiently good and significantly better than that of the purchasing business. Therefore, cost function of the financing business (monopoly) is declining unlike the cost function of the purchasing business (monopsony) which steadily increasing.

Concerning the specifications of the revenue and cost structures of the intra-group firms, from the business case presented before, remember that average unit operating revenue (price) $(R)=100-0,5 q, C_{f}=20-0,1 q$ and $C_{p}=20+0,1 q$, where $q$ represents the average unit output quantity, $\mathrm{C}_{\mathrm{f}}$ stands for the average unit operating cost of the financing business and $C_{p}$ is for the average unit operating cost of the purchasing business. Cost and revenue figures were given in dollars. Remember also that financing business is the monopoly being the exclusive fund provider and purchasing business is the monopsony being the exclusive fund providee or grantee. Given the findings obtained from the business case, it has been shown that, the (compromising) ICP is $\$ 27$ and the (compromising) output is 51 units, which is the common solution set for both the group firms.

In the previous discussions, establishing the interaction among ICPs, transfer outputs/quantities and operating profit or loss figures, we have clearly showed the effects of the ICP analysis on the regular financial statements, meaning the income statements and the balance sheets of the intra-group firms. Therefore, there is no need to build the existing interplay here again. Nonetheless, for the sake of constructing the financials, i.e. income statements and balance sheets, we need to first identify the operating profits or losses of the financing and purchasing businesses.

As the previous discussions have suggested, an operating profit equation might be written as follows: Expense)

Operating Profit (Loss) = Total Revenue (Operating Income) - Total Cost (Operating

\footnotetext{
${ }^{11}$ For the sake of brevity, the annual balance sheet of the purchasing division is not displayed here.
} 
More specifically, it has been demonstrated that, we may obtain the operating profit figures for the group firms such that: for the financing business:

Operating Profit $=\left[\mathrm{TR}^{\mathrm{f}}\right]-\left[\mathrm{TC}_{\mathrm{f}}\right]$ which may be restated as:

Operating Profit $=\left[I C P^{f} * q_{f}\right]-\left[C_{f} * q_{f}\right]$

where $\mathrm{TR}^{\mathrm{f}}$ stands for the total operating (sales) revenue of the financing business, $\mathrm{TC}_{\mathrm{f}}$ for the total operating cost volume of the financing business, $\mathrm{q}_{\mathrm{f}}$ for the corresponding (transfer) output of the financing business, and $\mathrm{C}_{\mathrm{f}}$ for the average unit operating cost volume of the financing business. As to be easily recalled from above, the ICP of the financing business is $\$ 27$ and transfer output is 51 units. Hence, the operating profit for the financing business will read the following:

Operating Profit $=[27 * 51]-[(20-(0.1 * 51)) * 51]$ which is $\$ 617$.

For the purchasing business:

Operating Profit $=\left[\mathrm{TR}^{\mathrm{p}}\right]-\left[\mathrm{TC}_{\mathrm{p}}\right]$ which may be restated as:

$$
\text { Operating Profit }=\left[I C P^{p} * q_{p}\right]-\left[C_{p} * q_{p}\right]
$$

where $\mathrm{TR}^{\mathrm{p}}$ stands for the total operating (sales) revenue of the purchasing business, $\mathrm{TC}_{\mathrm{p}}$ for the total operating cost volume of the purchasing business, $\mathrm{q}_{\mathrm{p}}$ for the corresponding (transfer) output of the purchasing business, and $\mathrm{C}_{\mathrm{p}}$ for the average unit operating cost volume of the purchasing business. Since the ICP of the purchasing business is $\$ 27$ and transfer output is 51 units, as in the case of the financing business, the operating profit for the purchasing business will read the following:

$$
\text { Operating Profit }=[27 * 51]-[(20+(0,1 * 51)) * 51]
$$

which is $\$ 97$. In the preceding section, the operating profit of the purchasing business was given to be $\$ 524$, now, it is tremendously lower than that. That is because it suffers from the lack of cost advantage, unlike the financing business whose operating profit figure increases from $\$ 524$ to $\$ 617$, as the following chapters will also unveil. The next section establishes the income statements of the financing and purchasing businesses respectively.

\subsubsection{The Income Statements of The Financing \& Purchasing Businesses}

For the financing business, a concise income statement may be given as follows. 
Table 8. Annual Income Statement For The Financing Business: Monopoly

Competition With Cost Advantage

\begin{tabular}{|l|r|}
\hline \multicolumn{2}{|c|}{ Annual Income Statement For The Financing Business } \\
For The Year Ending 2021 (in \$) \\
\hline \multicolumn{2}{|c|}{ Dec'21 } \\
\hline (1) Sales Revenue & 1,377 \\
\hline (2) Total Costs (-) & 760 \\
\hline (3= (1)-(2)) Operating Profit (OP) & 617 \\
\hline (4) Non-Operating Income & 0 \\
\hline (5) Non-Operating Expenses (-) & 0 \\
\hline (6= (3)+(4)-(5)) Income (Earnings) Before Taxes (EBT) & 617 \\
\hline (7) (Corporate) Income Taxes (-) & 123 \\
\hline [8= (6)-(7)] Net Income (Profit) After Taxes (NPAT) & 494 \\
\hline
\end{tabular}

Following the former monopoly case, being annual and in U.S. dollars, the upper income statement which is hypothetical is prepared for the year ending 2021. The items such as non-operating income or expenses are assumed to be zero. Further, applicable income tax rate is given as $20 \%$. Comparing with the income statement items of the financing division in the 'monopoly competition without cost advantage' section, we see that 'sales revenue' has increased from $\$ 1,240$ to $\$ 1,377$ while 'total costs' has also increased from $\$ 716$ to $\$ 760$. Therefore, 'operating profits' (from $\$ 524$ to $\$ 617$ ), 'income (earnings) before taxes’ (\$524 to \$617), '(corporate) income taxes' (from \$105 to \$123), 'net income (profit) after taxes (NPAT)' (from \$419 to \$494), have all changed in an upward direction.

For the purchasing division, a concise income statement may be given as follows. 
Table 9. Annual Income Statement For The Purchasing Business: Monopoly Competition With Cost Advantage

\begin{tabular}{|l|r|}
\hline \multicolumn{2}{|c|}{ Annual Income Statement For The Purchasing Business } \\
For The Year Ending 2021 (in \$) & Dec'21 \\
\hline \multicolumn{2}{|c|}{ \$, } \\
\hline (1) Sales Revenue & 1,377 \\
\hline (2) Total Costs (-) & 1,280 \\
\hline (3= (1)-(2)) Operating Profit (OP) & 97 \\
\hline (4) Non-Operating Income & 0 \\
\hline (5) Non-Operating Expenses (-) & 97 \\
\hline (6= (3)+(4)-(5)) Income (Earnings) Before Taxes (EBT) & 19 \\
\hline (7) (Corporate) Income Taxes (-) & 78 \\
\hline [8= (6)-(7)] Net Income (Profit) After Taxes (NPAT) & 0 \\
\hline
\end{tabular}

Similar assumptions and features holding for the financing division apply to the purchasing division as well. Comparing with the income statement items of the purchasing division in the 'monopoly competition without cost advantage' section, we see that 'sales revenue' has increased from $\$ 1,240$ to $\$ 1,377$ while 'total costs' has increased from $\$ 716$ to $\$ 1,280$. Therefore, 'operating profits' (from $\$ 524$ down to $\$ 97$ ), 'income (earnings) before taxes' (\$524 down to \$97), '(corporate) income taxes' (from \$105 down to \$19), 'net income (profit) after taxes (NPAT)' (from \$419 down to \$78), have all changed in a downward direction. The reason for the sharp reduction in the profit figures of the purchasing division is that it has cost disadvantage relative to the financing division, which accounts for such a fundamental and negative change in its financial statement, as mentioned several times.

Since we have established the income statements of the intra-group firms which are corporate income taxpayers due to their resulting (positive) EBT volumes, we can now construe their balance sheets as follows. As the EBT volumes of both the group firm are positive, they will pay corporate taxes.

\subsubsection{The Balance Sheets of The Financing \& Purchasing Businesses}

From the income statement accounts, we got 'provision for taxes' (corporate income taxes), 'earnings before taxes' (tax base/taxable income) and 'net profit after tax balances' (net profit for the period). We have seen that provision for taxes or tax provisions and net profit for the period are the figures we need to incorporate into the balance sheets of the intragroup firms as given above. 


\begin{tabular}{|l|l|}
\hline $\begin{array}{l}\text { (Corporate) Income Taxes (-) } \\
\text { Net Income (Profit) After Taxes (NPAT) }\end{array}$ \\
\hline$\sqrt{\text { Provision For Taxes }}$ & \\
\hline Net Profit For The Period & 123 \\
\hline
\end{tabular}

Figure 5. Transforming The Relevant Income Statement Accounts to The Balance Sheet Accounts of The Financing Business: Monopoly Competition With Cost Advantage (in \$)

The hypothetical balance sheet of the financing division may hence be established as follows.

Table 10. Annual Balance Sheet of The Financing Business: Monopoly Competition With Cost Advantage

Annual Balance Sheet of The Financing Business As of The Year Ending 2021 (in \$)

\begin{tabular}{|l|r|}
\hline Assets & Dec'21 \\
\hline Current Assets & 288 \\
\hline Cash & 517 \\
\hline Banks & 150 \\
\hline Inventories & 50 \\
\hline Other Current Assets & 1,005 \\
\hline Total Current Assets & 44 \\
\hline Net Fixed Assets & 10 \\
\hline Other Noncurrent Assets & 54 \\
\hline Total Non-Current (Fixed) Assets & $\mathbf{1 , 0 5 9}$ \\
\hline & Dec'21 \\
\hline Total Assets & \\
\hline
\end{tabular}




\begin{tabular}{|l|r|}
\hline Accounts Payable & 58 \\
\hline Provision For Taxes & 123 \\
\hline Other Current Liabilities & - \\
\hline Total Short-Term Liabilities & 181 \\
\hline Long-Term Debt & 120 \\
\hline Other Long Term Liabilities & 30 \\
\hline Total Long-Term Liabilities & 150 \\
\hline Total Liabilities & $\mathbf{3 3 1}$ \\
\hline & 234 \\
\hline Owner's Equity & 494 \\
\hline Contributed Capital & $\mathbf{7 2 8}$ \\
\hline Net Profit For The Period & $\mathbf{1 , 0 5 9}$ \\
\hline Total Equity & \\
\hline Total Liabilities \& Owner's Equity & \\
\hline
\end{tabular}

In the balance sheet above, as with the discussions in the previous sections, accounts (figures) except for the net profit for the period and provision for taxes are hypothetical. Notice that the change (increase) in 'banks' which is \$93 (from \$424 to \$517) can be explained by the change (increase) in earnings before taxes account (from $\$ 524$ to $\$ 617$ ). One should argue here that it does not have to be so always, which would be correct. However, given the hypothetical accounts above, it does not make sense that the intra-group firm may keep an amount of $\$ 93$ in cash, as the opportunity cost of holding that money within will be significantly high. Debiting the banks account will lead the division to earn at least a reasonable amount of interest yields. More than that, wherever \$93 is suggested to be posted in the upper balance sheet, it would not change the insight it provides; therefore, it is not so important to us.

Comparing with the balance sheet items of the financing division in the 'monopoly competition without cost advantage' section, we see that 'net profit for the period' has changed from \$419 to $\$ 494$ and 'provision for taxes' has changed from \$105 to \$123. Therefore, 'banks' (from \$424 to \$517), 'total current assets' (\$912 to \$1,005), 'total assets' (from \$966 to \$1,059), 'total short-term liabilities’ (from \$163 to \$181), 'total liabilities' (from \$313 to \$331), 'total equity' (from \$653 to \$728) and 'total liabilities \& owner’s equity' (from $\$ 966$ to $\$ 1,059$ ) have all changed in an upward direction.

As in the case of the financing division, the purchasing division will need to embed the relevant income statement accounts (figures) into its balance sheet. ${ }^{12}$ In there, accounts

\footnotetext{
${ }^{12}$ For the sake of brevity, figure and table displaying this transformation are not reported here.
} 
(figures) except for net profit for the period and provision for taxes are hypothetical. Comparing with the balance sheet items of the purchasing division in the 'monopoly competition without cost advantage' section, we note that 'net profit for the period' has decreased from \$419 down to \$78 and 'provision for taxes' has decreased from \$105 to \$19. Therefore, 'banks' (from \$424 to \$0), 'cash' (from \$288 to \$285), 'total current assets' (\$912 to \$485), 'total assets' (from \$966 to \$539), 'total short-term liabilities’ (from \$163 to \$77), 'total liabilities' (from \$313 to \$227), 'total equity’ (from \$653 to \$312) and 'total liabilities \& owner’s equity’ (from \$966 to \$539) have all changed (reduced). The change (decrease) in 'banks' and 'cash' which is $\$ 427$ can be explained by the change (decrease) in the earnings before taxes account (from \$524 to \$97). These produce the following statements:

Proposition 1a: Given that businesses transact with each other under bilateral monopoly competition; ceteris paribus, the operating profit (OP) figure of the business with cost advantage will be higher than the operating profit figure of the business without cost advantage.

Proposition 1b: Given that businesses transact with each other under bilateral monopoly competition; ceteris paribus, asset size, earnings before interest and taxes (EBIT), earnings before taxes (EBT) and hence net income/profit after tax (NPAT) figures of the business with cost advantage will always be higher than asset size, EBIT, EBT and therefore NPAT figures of the business without cost advantage.

\section{CONCLUSION}

When the group or holding companies or when the divisions or units in a company make transactions with each other, an inter-company price (ICP) is established as a result to settle those transactions in such a way that the transacting parties (companies or divisions) would need to agree. ICP has been examined in the financial literature for quite a while. It dates back to early-to-mid $20^{\text {th }}$ century. However, the ICP literature that connects economics with accounting is still narrow and is in need of growing. In particular, literature is silent in showing the effects of ICP on corporate financial reporting directly. To the best of our awareness, this is the first study that was motivated to break the silence. This paper has developed a theory of ICP and shown its direct association with corporate financial reporting in general and corporate financial statements in particular. For this purpose, cost advantage was served to build an economic theory and operating profit was served as a catalyst to apply the theory into accounting practice. In other words, cost advantage and operating profits were considered and constructed as keys to show and explain the interplay between ICP and corporate financial statements.

This paper has examined monopoly competition "with and without cost advantage" in the light of business cases. Existence of cost advantage was assumed to be an edge that may arguably result from decent corporate governance structures of the group firms under monopoly. This paper has established the equilibria that were obtained under monopoly competition vis-à-vis "with cost advantage" versus "without cost advantage" scenarios. It has also yielded a remedy that may solve the duality problem between the parties of monopoly. As motivated, this paper has made an application to corporate financial reporting world. It has shown the impacts of ICP analysis on the corporate financial statements for the business organizations that run their activities under monopoly competition. 
Specifically, it was proposed that given that businesses transact with each other under bilateral monopoly competition; ceteris paribus, the operating profit figure of the business with cost advantage will be higher than the operating profit (OP) figure of the business without cost advantage. Further, it was also proposed that given that businesses transact with each other under bilateral monopoly competition; ceteris paribus, asset size, earnings before interest and taxes (EBIT), earnings before taxes (EBT) and hence net income/profit after tax (NPAT) figures of the business with cost advantage will always be higher than asset size, EBIT, EBT and therefore NPAT figures of the business without cost advantage.

\section{REFERENCES}

Amershi, Amin H. - Cheng, Peter (1990), “ Intrafirm Resource Allocation: The Economics Of Transfer Pricing And Cost Allocations In Accounting ”, Contemporary Accounting Research, 7, pp. 61-99.

Baldenius, Tim - Edlin, Aaron - Reichelstein, Stefan (1999(A)), “ Market-Based Transfer Prices And Intracompany Discounts ”, @Http://ssrn.Com/Abstract=155650 Or Doi: 10.2139/ssrn.10.2139/ssrn.155650.

Baldenius, Tim - Reichelstein, Stefan - Sahay, Savita A. (1999(B)), “ Negotiated Versus CostBased Transfer Pricing ”, Review Of Accounting Studies, 4, pp. 67-91.

Baldenius, Tim - Melumad, Nahum D. - Reichelstein, Stefan (2004), “ Integrating Managerial And Tax Objectives In Transfer Pricing ”, The Accounting Review, 79, pp. 591-615.

Baldenius, Tim - Reichelstein, Stefan (2006), “ External And Internal Pricing In Multidivisional Firms”, Journal Of Accounting Research, 44, pp. 1-28.

Bierman, Harold (1959), “ Pricing Intracompany Transfers”, The Accounting Review, 34, pp. 429-432.

Buus, Tomas (2006), “ The Economics Of Transfer Pricing: A Review ”, @Http://Papers.Ssrn.Com/Sol3/Papers.Cfm?Abstract_Id=954333.

Brust, Peter - Fesmire, James - Truscott, Michael (2008), “ The Impact Of Incremental Cost Increases In Successive Monopoly With Downstream Promotion ”, Journal Of Applied Economics And Policy, 27, Issue 1, pp. 33-46.

Cook, Paul W. (1955), “ Decentralization And The Transfer Price Problem ”, Journal Of Business, 28, pp. 87-94.

Cravens, Karen S. (1997), “ Examining The Role Of Transfer Pricing As A Strategy For Multinational Firms ”, International Business Review, 6, pp. 127-145.

Dabson, Paul W. - Waterson, Michael (2007), “ The Competition Effects Of Industry-Wide Vertical Price Fixing In Bilateral Oligopoly ”, International Journal Of Industrial Organization 25, Issue 5, pp. 935-962. 
Dawson, Peter C. - Miller, Stephen M. (2000), “ Transfer Pricing In The Decentralized Multinational Corporation ”, University Of Connecticut, Economics Department, Wp. No. 2000-06r.

Dean, Joel (1955), “ Decentralization And Intra-Company Pricing ”, Harvard Business Review, 333, pp. 65-74.

Edlin, Aaron S. - Reichelstein, Stefan (1995), “ Specific Investment Under Negotiated Transfer Pricing: An Efficiency Result”, The Accounting Review, 70, pp. 275-291.

Greene, James (1969), “ Intercorporate Pricing Across National Frontiers ”, The Conference Board Record, October, pp. 43-48.

Göx, Robert F. - Schöndube, Jens R. (2004), “ Strategic Transfer Pricing With Risk-Averse Agents ”, Schmalenbach Business Review, 56, pp. 98-118.

Hart, Oliver D. (1983), “ The Market Mechanism As An Incentive Scheme ”, The Bell Journal Of Economics, 14, pp. 366-382.

Hirshleifer, Jack (1956), “ On The Economics Of Transfer Pricing ”, Journal Of Business, July.

Horst, Thomas S. (1971), “ The Theory Of The Multinational Firm: Optimal Behavior Under Different Tariff And Tax Rates ”, Journal Of Political Economy, September-October, pp. 1059-1072.

Johnson, Edward - Johnson Nicole B. - Pfeiffer, Thomas (2016), “ Dual Transfer Pricing With Internal And External Trade ”, Review Of Accounting Studies, 21, Issue 1, pp. 140164.

Johnson, Nicole B. - Loffler, Clemens - Pfeiffer, Thomas (2018), “ An Evaluation Of Alternative Market-Based Transfer Prices ”, Contemporary Accounting Research, 35, Issue 4, pp. 1868-1887.

Jie-A-Joen, Clive - Sleuwaegen, Leo (1997), “ Multinational Firm Behaviour Under Different Tarif And Tax Rates: Effects From Strategic Interaction In The Host Country ”, De Economicst, 145, pp. 65-89.

Kaiser, Daniel (2014), “ Transfer Pricing And Demand Interdependence: Negotiated Versus Cost-Based Methods In The Presence Of Multiple Buying Divisions ”, Die Betriebswirtschaft, 74, Issue 6, pp. 371-389.

Kassicieh, Suleiman K. (1981), “ International Intra-Company Transfer Pricing ”, Operations Research, 29, pp. 817-828.

Kaymaz, Mike Onder (2009), “ Transfer Pricing, Cost Advantage And Operating Profits Under Imperfect Competition: Theory And Application ”, Unpublished Doctoral Dissertation, Bocconi University. 
Kaymaz, Mike Onder - Kaymaz, Ozgur (2012), “ Operating Drivers Which Explain Bank Credit Margins In Deposit Banks: The Case Of Turkey ”, Journal Of The World Of Accounting Science, 14, pp. 167-184.

Kaymaz, Mike Onder - Pehlivan, Mustafa - Kaymaz, Ozgur (2010), “Size Does Matter: Evidence From Ise-Listed Banks”, Jassa: The Finsia Journal Of Applied Finance, 3, pp. 18-26.

Kaymaz, Mike Onder - Kaymaz, Ozgur - Sayar, Zafer (2015), “Corporate Financial Reporting And Performance: A New Approach”, Palgrave Macmillan, U.K.

Kaymaz, Mike Onder - Kaymaz, Ozgur (2019), "Learning From Oligopoly Rivalry: Implications For Business Financial Statements”, Journal Of Accounting And Management Information Systems, 18, Issue 4, pp. 509-558.

Korn, Evelyn - Lengsfeld, Stefan (2007), “ Duopolistic Competition, Taxes And The Arm'sLength Principle”, @Http://Papers.Ssrn.Com/Sol3/Papers.Cfm?Abstract_Id=871219.

Loffler, Clemens (2017), “ Transfer Prices For Coordination Under Decentralized Decision Making ”, Game Theory In Management Accounting, January, pp.71-89.

Machlup, Fritz (1967), “ Theories Of The Firm: Marginalist, Behavioral, Managerial ”, American Economic Review, 57, pp. 1-33.

Mathis, Stefan A. - Koscianski, Janet (2002), Microeconomic Theory: An Integrated Approach, Prentice Hall: NJ, USA.

Matsui, Kenji (2012), “ Cost-Based Transfer Pricing Under R\&D Risk Aversion In An Integrated Supply Chain ”, International Journal Of Production Economics, 139, Issue 1, pp. 69-79.

Merville, Larry J. - Petty, J. William (1978), “ Transfer Pricing For The Multinational Firm”, The Accounting Review, October, pp. 935-951.

Narayanan, Vilangadu G. - Smith, Michael (2000), “ Impact Of Competition And Taxes On Responsibility Center Organization And Transfer Prices ”, Contemporary Accounting Research, 17, pp. 497-529.

Pfeiffer, Thomas - Wagner, Joachim (2007), “ Internal Markets Or Hierachies: Transfer Prices Or Budgets? ”, Journal Of Economics And Business, 59, pp. 241-255.

Pfeiffer, Thomas, Schiller, Ulf - Wagner, Joachim (2011), “ Cost-Based Transfer Pricing ”, Review Of Accounting Studies, 16, Issue 2, pp. 219-246.

Schjelderup, Guttorm - Sørgard, Lars (1997), “ Transfer Pricing As A Strategic Device For Decentralized Multinationals ”, International Tax And Public Finance, 4, pp. 277-290.

Schmidt, Klaus M. (1997), “ Managerial Incentives And Product Market Competition ”, Review Of Economic Studies, 64, pp. 191-213. 
Schon, Wolfgang (2012), “ Transfer Pricing - Business Incentives, International Taxation And Corporate Law ”, Fundamentals Of International Transfer Pricing In Law And Economics, pp. 47-67.

Shor, Mikhael - Chen, Hui (2009), “ Decentralization, Transfer Pricing, And Tacit Collusion ”, Contemporary Accounting Research, 26, No. 2, pp. 581-604.

Thomas, Arthur L. (1980), A Behavioral Analysis Of Joint Cost Allocation And Transfer Pricing, The University Of Lancaster, International Center For Research In Accounting, pp. 1-322.

Yao, Jen-Te (2013), “ The Arm’s Length Principle, Transfer Pricing, And Location Choices ”, Journal Of Economics And Business, 65, January-February, pp. 1-13.

Zhao, Laixun (2000), “Decentralization And Transfer Pricing Under Oligopoly ”, Southern Economic Journal, 67, pp. 414-426. 
